\title{
THE NEW KINGDOM IN NUBIA: NEW RESULTS FROM CURRENT EXCAVATIONS ON SAI ISLAND*
}

\author{
JULIA BUDKA
}

\begin{abstract}
Settlement patterns in Nubia (northern Sudan) in the 2nd Millennium BC are currently investigated by diverse archaeological missions. This new fieldwork will potentially contribute to a better understanding of the Egyptian involvement in Nubia during the New Kingdom. At present, little is known about the architecture, structure, social stratification and material culture of Pharaonic settlements in Nubia from this period. This paper will discuss the current state of knowledge regarding the Egyptian presence in Upper Nubia during the $18^{\text {th }}$ Dynasty taking Sai Island as a case study. Recent fieldwork in the Pharaonic town of Sai Island, conducted within the framework of the European Research Council Project AcrossBorders, is focusing both on living conditions and on the general layout of the town. The results of work from 2013 to 2014 in the areas SAV1 East and SAV1 West will be summarised.
\end{abstract}

\section{Introduction}

The northern part of the modern Sudan, so-called Nubia, ${ }^{1}$ is very rich in archaeological remains and monuments. Temples, fortresses and settlements in Lower Nubia (Wawat), the northern area, have been submerged by the Aswan dam after having been partly documented during the UNESCO campaign. ${ }^{2}$ In the area between the Second and the Third Cataract and reaching further upstream, the region of so-called Upper Nubia (Kush), a number of sites is still preserved. The Upper Nubian monuments are mostly stone temples of the New Kingdom like the impressive temple of Soleb. However, these temples were originally integrated into settlements and fortified towns. Settlement places are at present not fully explored but provide much potential for understanding the past occupation in Nubia.

It is well known that the Egyptian involvement in Nubia was intensive during the New Kingdom. ${ }^{3}$ However, several aspects are still unclear and have been debated. This holds especially true for the questions of early Egyptian presence in Kush during the $18^{\text {th }}$ Dynasty and the social stratification of Egyptian sites. Thanks to current fieldwork, particularly at Sesebi, Sai Island and Amara West, our state of knowledge has markedly improved in the last few years.

* This paper is based on a lecture delivered in Pisa, 27/05/2014 - I would like to thank Marilina Betrò for the kind invitation and for facilitating my stay in Italy.

1 See, e.g., Lacovara 2012, 5-9.

${ }^{2}$ Cfr. FisHer 2012, 10.

${ }^{3}$ See, most recently, Fisher 2012, 25-33; ZiBeLIUS-Chen 2013, 135-155. 
New archaeological evidence for the establishment of Pharaonic administration in Upper Nubia was discovered on Sai. Taking the site as a case study, this paper presents the current state of knowledge regarding the Egyptian manifestation in Kush during the $18^{\text {th }}$ Dynasty.

\section{Upper Nubia during the late Second Intermediate Period and early New Kingdom}

The Kerma Kingdom of Kush ${ }^{4}$ with its capital at the Third Cataract is known as a substantial rival of the Theban $17^{\text {th }}$ Dynasty. Among others, this is illustrated by the Kamose stelae ${ }^{5}$ and by recent findings at Elkab. ${ }^{6}$ Kush (Upper Nubia) was ruled by the Kerma king and his vassals. The exact limits of Kerma influence towards the North are still partly unclear, but Wawat (Lower Nubia) seems to have been under independent control of several local rulers, cooperating with the ruler of Kerma. ${ }^{7}$ At the end of the Second Intermediate Period, Wawat was soon again controlled by the Egyptians. ${ }^{8}$ Epigraphical sources from Buhen and other finds suggest that Kamose managed to extend his sphere of influence into Lower Nubia. ${ }^{9}$

Sai Island, Egyptian $S^{3} \cdot t^{10}$ a large community of Kerma Nubians is attested prior to the $18^{\text {th }}$ Dynasty from the Ancient to the Classical Kerma period. ${ }^{11}$ As the northern stronghold of the Kerma kingdom, Sai was in a prominent location just south of the Batn el-Hagar and probably prevented the unchecked Egyptian expansion towards the South. Several Nubian campaigns are attested by king Ahmose Nebpehtyra. Although the precise setting of his battles is unknown, ${ }^{12}$ it can be assumed that he was concerned with the northernmost outpost of the rival kingdom of Kush on Sai Island. ${ }^{13}$ A number of textual sources from Sai Island refer to Ahmose, including a sandstone statue of the king, presumably set up in the small local temple. ${ }^{14}$ Sai functioned most probably as a "bridgehead into Kush proper and a secure launching pad for further campaigns," 15 enabling the following kings of the $18^{\text {th }}$ Dynasty, especially Thutmose I, to go further South. ${ }^{16}$

Thutmose I has left a number of texts referring to his activities in Upper Nubia, among others royal stelae at Tombos and Kurgus. ${ }^{17}$ A stela by his son Thutmose II at Aswan mentions fortresses, mnn.w, of Thutmose I. ${ }^{18}$ The location of these fortresses is disputed: there are no

\footnotetext{
4 For the town of Kerma, see most recently Bonnet 2014, 16-242, 250-253.

Cfr. O'ConNor 1997, 62-63; ZiBelius-Chen 2013, 136-137.

6 Davies 2010, 223-240. Cfr. also Zibelius-Chen 2013, 135; Valbelle 2014, 107.

7 Sмітн 2003, 80. See also the recent summaries by Mоккот 2013, 924; Valbelle 2014, 107.

8 TÖRÖK 2009, 158-159.

9 See SMith 2001, 80; TÖRÖK 2009, 103-118; Fisher 2012, 24; MüLler 2013, 5.

10 For the toponym $\breve{S} 3$. $t$ see Devauchelle, Doyen 2009, 33-37.

11 Attested by huge Kerma tumuli graves on the island, see GratiEn 1986, PASSIM.

12 For Ahmose's activities in Nubia, cfr. KAHN 2013, 17-18 with references and most recently DAVIES 2014.

13 DAvies 2005, 51; see also TÖrÖK 2009, 183.

14 See L. Gabolde 2011-2012, 118-120.

15 DAVIES 2005, 51.

16 Vercoutter 1973, 7-38; see also TörÖK 2009, 158-159 and Morkot 2013, 913.

17 Davies 1998, 26-29; BudKa 2005, 108-109; Davies 2008, 47; Valbelle 2014, 107.

18 TӧвÖK 2009, 161 with note 32; see also GABOLDE 2011-2012, 136 with note 77.
} 
archaeological remains at Tombos ${ }^{19}$ or at Gebel Barkal. New finds at Dukki Gel indicate that one of these Egyptian fortresses might have been in close proximity to the capital Kerma. ${ }^{20}$ Architecture and artefacts at Kerma attest to a contemporaneous heyday of power of the king of Kerma. ${ }^{21}$

Ongoing fieldwork at the major early New Kingdom sites in Upper Nubia (Sai Island, Sesebi, Tombos, Dukki Gel) has yielded structures and finds dating to the early $18^{\text {th }}$ Dynasty, especially to Thutmose $\mathrm{I}^{22}$ - the archaeological work therefore complements the textual evidence. By the time of Thutmose I, there was an increased presence of Egyptians in the area which went hand in hand with a rapid Egyptianisation, ${ }^{23}$ although Egyptian influence in the area of the Third Cataract remained unstable and a Nubian rebellion is attested during the reign of Thutmose II..$^{24}$ The Egyptian conquest of Upper Nubia came to an end with the final victory of Thutmose III against the kingdom of Kerma - the realm of Egyptian domination now reached as far as to the area of the Fourth Cataract. ${ }^{25}$

\section{Settlements of the New Kingdom in Upper Nubia}

Egyptian towns founded in the area known today as Upper Nubia in Northern Sudan during the period of the New Kingdom offer the unique chance to conduct a detailed analysis of domestic life at the junction of Egyptian and Nubian culture. Compared to sites located in modern Egypt, these Upper Nubian sites are generally better preserved and more accessible because they are not located beneath the present houses or cities. ${ }^{26}$

The current understanding of settlement patterns in Upper Nubia (Kush) is the following: the general organisation and administration are quite well understood although it is unclear which site functioned as the administrative centre prior to Soleb (from Amenhotep III to the early $19^{\text {th }}$ Dynasty) and Amara West (from Seti I until the end of the New Kingdom). ${ }^{27}$ There are several indications that Sai Island was the Egyptian headquarters in Kush from at least Thutmoside times onwards. ${ }^{28}$ Most studies have concentrated on economic and strategic aspects of the sites. As it is for example well illustrated by the site of Soleb there was a tendency to focus on stone temples respectively the cemeteries. ${ }^{29}$ The urban remains and mud brick structures have been rather insufficiently studied. There is no doubt that temples were key elements of the towns and the location of the main sites in the Abri-Delgo-reach (Sesebi, Soleb, Tombos, Sai) seems to be connected with the character of the area as a rich gold ore

19 Cfr. BudKa 2005, 113.

${ }^{20}$ Valbelle 2012, 447-464; Valbelle 2014, 107. See also Gabolde 2011-2012, 135-136.

${ }^{21}$ Valbelle 2014, 107.

${ }^{22}$ See in particular Bonnet 2012, 67, fig. 9; Valbelle 2014, 107.

${ }^{23}$ Cfr. МоRкот 2013, 947; Valbelle 2014, 107.

${ }^{24}$ Bonnet 2012, 71; Zibelius-Chen 2013, 138 with further references; Valbelle 2014, 107.

${ }^{25}$ Sмітн 1995, fig. 6.1; ТӧвÖк 2009, 165; Ziвelius-Chen 2013, 138.

${ }^{26}$ BUDKa, DOYEn 2012/2013, 167.

${ }^{27}$ Cfr. TÖRÖK 2009, 180.

${ }^{28}$ See below and cfr. BUDKA 2013, 78-87; BUDKA forthcoming a and c.

${ }^{29}$ Cfr. Schiff Giorgini 1965-2003. 
region (see below).$^{30}$ The rural occupation and smaller villages of Kush are difficult to trace, ${ }^{31}$ but in some areas indirect evidence derives from cemeteries. ${ }^{32}$

The better-understood settlements in Kush all fall into the category of so-called Nubian temple towns - these are fortified towns built in the New Kingdom with an enclosure wall and a prominent temple within the settlement area. ${ }^{33}$ The last few years have seen an increase in archaeological fieldwork on these sites. Excavations at Amara West, ${ }^{34}$ Sesebi $^{35}$ and on Sai Island ${ }^{36}$ were resumed after long periods of neglect. This new boom in urban archaeology in Upper Nubia has much potential for an understanding of settlement patterns in the region. Eventually, it will be possible to assess the diachronic and regional development of the settlements in the area as well as the local properties of the individual sites at a synchronic level.

New work at Sesebi, under the direction of Kate Spence and Pamela Rose since 2008, concentrates on a re-assessment of the work by the EES in the 1930s. The most important result is that structures and material remains, especially pottery, have been found which predate the reign of Akhenaten. It is very likely that the site was already founded at the very beginning of the $18^{\text {th }}$ Dynasty. ${ }^{37}$

Recent work on Sai Island as the focus of this paper will be described below.

One of the largest current projects in Upper Nubia, directed by Neal Spencer since 2006, is at Amara West. Both the New Kingdom town and cemeteries are currently being explored and have revealed amazing new finds. ${ }^{38}$ In 2014, a survey was conducted in the surroundings, expanding the scope of the research to the hinterland and raising fundamental questions of patterns of occupation. ${ }^{39}$

Taking the ongoing research into account, the present state of settlement archaeology in Upper Nubia can be characterised as follows: (1) Dating: There are changing views regarding the earliest and latest occupation on various sites, especially as fieldwork is continuing. At several sites, e.g. at Sesebi, Egyptian presence, most likely, started earlier than previously thought. Amara West has produced interesting evidence that the Egyptian presence might have lasted beyond the New Kingdom. ${ }^{40}(2)$ Social stratification: There is no common understanding regarding the social interconnections and power hierarchies of Egyptians and Nubians in the Egyptian towns established in Upper Nubia during the New Kingdom. Especially

${ }^{30}$ Cfr. Spence, Rose et Al. 2009, 38-39. See most recently Klemm, Klemm 2013, passim; Darnell 2013, 824-829.

31 The New Kingdom occupation in Upper Nubia was recently summarized by EDWARDs 2012, 66-74, see especially 67.

32 For the general importance of funerary remains to reconstruct settlement patterns, see SEIDLMAYER 2006.

33 Cfr. Kemp 1972a, 651-656; Morris 2005, 5; Graves 2011, 63.

34 E.g. SPEnCER 2010, 15-24; SPEnCER 2014b, 457-485.

35 E.g. Spence, Rose et Al. 2009, 38-46; Spence, Rose et al. 2011, 34-39.

36 E.g. Doyen 2009, 29-49; BudKa 2011, 23-33; Doyen 2014, 367-375.

37 Spence, Rose et al. 2009, 39, 42.

38 See, e.g., Spencer 2009, 47-61; SPencer 2010, 15-24; Spencer 2014a, 42-61; Spencer 2014b, 457 485; SPENCER, SteVEns, BINDER (EDS.) 2014, passim with further references.

39 Stevens 2014, 22.

40 Cfr. Binder 2011, 39-53. 
as the projects at Sai, Amara West and Tombos are applying a new approach to the social stratification, entanglement, mixture and acculturation with important impact by indigenous elements are the phenomena currently thought to be most relevant contrasting with the terms of separation and Egyptian centred-views of earlier archaeologists. ${ }^{41}$ (3) Background and landscape: Modern technical advances have become important for settlement archaeology in Nubia and at most sites the environmental settings are getting explored. ${ }^{42}$ Various aspects of archaeometry are conducted by the missions working in the field. Especially geoarchaeological and interdisciplinary applications like soil sampling, micromorphology and isotope analysis are common and the analysis of the material culture is undertaken from a multi-perspective level, including various scientific analyses (e.g. iNAA) and different approaches. ${ }^{43}$

\section{1 The Gold of Kush}

Nubia is famous for its rich supply of gold and it is well known that Nubian gold was among the main Egyptian economic interests during a long time span. ${ }^{44}$ There is increasing evidence that the rich gold occurrence in the Abri-Delgo-reach influenced the foundation of the New Kingdom sites there ${ }^{45}$ and that the dense distribution of New Kingdom temples in this region might be connected to the gold of Kush. ${ }^{46}$ Recent archaeological fieldwork at Sesebi, ${ }^{47}$ Sai Island, ${ }^{48}$ Tombos and Amara West ${ }^{49}$ seem to support this association of the sites with gold exploitation. According to Klemm \& Klemm, a significant change in gold processing and prospecting took place in the New Kingdom with the important "introduction of the grinding mill to the mining industry." ${ }^{50}$ This new type of mill allowed the increased exploitation of auriferous quartz vein systems and is attested in all New Kingdom sites mentioned above.

According to Egyptian texts, the amount of gold coming from Kush seems to differ from the one from Wawat. ${ }^{51}$ This is especially the case during the reign of Thutmose III when much more gold of Wawat was registered. From the time of Amenhotep III onwards, Kush seems to have gained in importance as a gold mining area as, for example, representations in the tomb of viceroy Huy illustrate. ${ }^{52}$ Textual evidence implies a decline in gold production in Ramesside times, ${ }^{53}$ future archaeological fieldwork has the potential to confirm or modify this perception.

${ }^{41}$ Cfr. Van Pelt 2013, 523-550; Smith 2014, 1-4; Smith, Buzon 2014, 431-442; Spencer 2014A, $42-61$.

42 See Spence, Rose 2009, 43-45; Spencer, Macklin, Woodward 2012, 37-47. Cfr. also Edwards 2012 , 67.

${ }^{43}$ Cfr. Spencer 2014b, 482; BudKa forthcoming b.

${ }^{44}$ Cfr. Vercoutter 1959, 120-153; Müller 2013, 74-79.

45 See Klemm, Klemm 2013, 569-570; also Darnell 2013, 828.

46 Klemm, Klemm 2013, 568-570.

47 SPence, Rose 2009, 38-39.

48 See Klemm, KLemm 2013, P. 570-572; BudKa forthcoming b.

49 Personal information kindly provided by St. T. SMITH and N. SPENCER, publication forthcoming.

50 Klemm, KLemm 2013, 9.

51 Vercoutter 1959, 135.

52 Cfr. Zibelius-Chen 2013, 140.

53 Vercoutter 1959, 135. 


\subsection{The New Kingdom Town of Sai Island}

A fortified Pharaonic town was built on the eastern bank of the large island of Sai in the New Kingdom (Fig. 1). Little is known about its eastern part and former scholars assumed that the eastern wall had collapsed into the Nile. ${ }^{54}$ Recent fieldwork and a geological survey of the sandstone cliff allow modifying this assessment: The state of preservation of the $18^{\text {th }}$ Dynasty remains close to the river is very poor, but possible remains of an eastern town wall have been located by Erich Draganits in $2014 .{ }^{55}$ There are no signs of a substantial collapsing of the cliff. The east-west extension of the Pharaonic town is therefore much shorter than previously thought: a maximum of $120 \mathrm{~m}$ instead of $140 \mathrm{~m}$ can be assumed (Fig. 2). ${ }^{56}$ This will be investigated by means of excavations in the forthcoming season.

At present, around two thirds of the New Kingdom fortified town are still unexcavated and a detailed assessment of the town's evolution is therefore not possible (Fig. 3) ${ }^{57}$ Its southern part with a temple and a residential quarter was investigated by a French Mission in the 1950s and1970s. The area around Temple A was also excavated in the 1970s. From 2008-2012, fieldwork was conducted by the Sai Island Archaeological Mission of Lille 3, directed by D. Devauchelle, along the northern enclosure, at a site named SAV1 North. ${ }^{58}$

In the southern part of the town different quarters were identified: the so-called governor's residence (SAF2) with a large columned hall $(15.3 \times 16.2 \mathrm{~m})$ and mud-brick paving in the east ${ }^{59}$ a central domestic quarter $\mathrm{H}$ comprising a cluster of five houses; and a western quarter (SAF5), consisting of several rectangular storage rooms and circular silos. ${ }^{60}$ These quarters are organised along north-south and east-west axes and reflect the orthogonal planning of the town. Parallels for such a layout can be found at other New Kingdom temple towns, especially at Buhen, Amara West and Sesebi. ${ }^{61}$

One of the focal points of the early investigation of the southern part of the town SAV1 was the small sandstone temple. Temple A, c. $10 \mathrm{~m}$ in width, finds close parallels with other Egyptian sites in Nubia. ${ }^{62}$ Foundation deposits ${ }^{63}$ confirm that Thutmose III built the earliest cella $^{64}$ of this temple; a building inscription on a pillar (S. 1) written in the name of viceroy Nehy describes another building phase in year 25 of this king. ${ }^{65}$

${ }^{54}$ Geus 2004, 115, fig. 89 (based on the reconstruction by Azim 1975, 94, pl. II).

${ }^{55}$ See BUDKA forthcoming $a$ and $b$.

${ }^{56}$ Cfr. BudKa forthcoming c.

${ }^{57}$ See BudKa, Doyen 2012/2013, 181-182.

${ }^{58}$ Doyen 2009, 17-20; Doyen 2014, 367-375. See also the summary by BUDKA, Doyen 2012/2013, 168-171.

${ }^{59}$ For a detailed assessment of SAF2 see BUDKA forthcoming $\mathrm{c}$.

${ }^{60}$ AzIm 1975, 98, pl. 4; DOYEN 2009, colour pl. 9.

${ }^{61}$ Kemp 1972A, 651-653. Cfr. also Morris 2005, 195-197.

${ }^{62}$ For a comparison between the New Kingdom temples at Kumma, Semna and Sai see AzIM AND CARLOTTI 2011, 44, pl. XVI.

${ }^{63}$ See Thill 1997, 105-117.

${ }^{64}$ Azim, Carlotti 2011, 39, 45.

${ }^{65}$ First mentioned by BreAsted 1908, 98 and published by Vercoutter 1956, 74-75, DOC. 13; see also Geus 2004, 115; AzIm, CARLotTI 2011, 46, note 84. A revised copy with important additional readings is now presented by DAVIES 2014. 


\section{New Evidence from Sai Island}

The starting point for new fieldwork within the Pharaonic town of Sai was the lack of understanding contextual aspects of the site: most importantly, its microhistory - the evolution and specific structure on a very detailed level - is still unclear; the character and density of occupation are open questions as are the general layout and relations with neighbouring sites. Fine dating of archaeological remains commenced in 2011with the study of the ceramics, but more stratified contexts are needed to closely assess the development of the town. ${ }^{66}$

The European Research Council project AcrossBorders conducted its first field season in January-March 2013, its second in January-February 2014. The most important results will be summarised in the following.

\subsection{Sector SAV1 East}

Aiming to achieve a more complete understanding of the layout of the $18^{\text {th }}$ Dynasty occupation at Sai, a new excavation area was opened in 2013 (SAV1 East), 30-50m north of the Temple A at the eastern edge of the town (Figs. 3 and 6). The new squares are located where very promising anomalies were present on the geophysical survey map, ${ }^{67}$ seemingly the outline of an orthogonal building. The structure is aligned with Temple $\mathrm{A}$ and the main north-south road, following the orientation of the buildings in the southern part of the town (SAV1) and suggesting a $18^{\text {th }}$ Dynasty date. ${ }^{68}$

\section{The earliest remains at SAV1 East}

The zone between Temple A and the new site (SAV1 East) has revealed early occupation remains with a number of small huts, workshop-like structures and storage facilities. Recently published by Azim, he could show that the remains are earlier than the stone temple, thus are pre-dating Thutmose III. ${ }^{69}$ Azim even proposed a dating prior to the New Kingdom, based on Kerma ceramics found associated with the structures and through comparison with similar structures at the Kerma village of Gism el-Arba. ${ }^{70}$

New evidence from SAV1 East allows linking the earliest levels there with the horizon around Temple A. A small plaster coated storage bin (feature 14) still held two complete pottery vessels in situ permitting a dating to the early $18^{\text {th }}$ Dynasty, excluding the Second Intermediate Period. ${ }^{71}$ Several fragments of Kerma vessels have also been found - for these the associated Egyptian material gives a dating to the early $18^{\text {th }}$ Dynasty up to Thutmose III. Consequently, it has to be stressed that there is no evidence for pre- $18^{\text {th }}$ Dynasty occupation at

${ }^{66}$ See BudKa 2011, 23-33; cfr. also BudKa, Doyen 2012/2013, 188-198.

${ }^{67}$ The magnetometer survey was conducted in 2011 by Sophie Hay and Nicolas Crabb, British School at Rome and the University of Southampton; I am grateful to Didier Devauchelle for the possibility to use these data.

${ }^{68}$ BUDKA 2013, 80-81.

${ }^{69}$ Azim, CARLotti 2011-2012, 34-36.

70 See Gratien 1995, 5-65; Gratien et al. 2003, 29-43; Gratien et al. 2003-2008, 21-35 and Azim, CARLOTtI 2011-2012, 35, note 59.

${ }^{71}$ BUDKA 2013, 82. 
SAV1 East or around the Temple A: there is no Kerma level predating the Egyptian occupation in this area of the Pharaonic town. The earliest remains in the as yet exposed parts of the town, comprising primarily workshop-like structures and storage facilities, date back to the time span of Ahmose Nebpehtyra up to Thutmose I. ${ }^{72}$

\section{The large building complex at SAV1 East}

In the northern area of SAV1 East regular outlines filled with sand were revealed just below the surface: these are the negative outlines visible on the results of the magnetometer survey. The Pharaonic building material, once forming the walls, has been hacked away almost completely, destruction events that can be associated with Medieval and Ottoman times. Adjacent to the sandy outlines, collapsed mud bricks, more or less in line with the plundered foundation part of the mud brick wall, were found. These bricks represent the remains of the foundation trenches for the New Kingdom walls, originally filled with loose gravel material and thrown in mud bricks. An undisturbed section of the foundation trench yielded a painted rim sherd (SAV1 East P57) of an Upper Egyptian Marl clay vessel. ${ }^{73}$ Such vessels decorated with bands in dark brown are known from other contexts in Egypt, from the Thutmoside era onwards. This vessel therefore provides a good dating indication for the building: Dynasty 18, but not earlier than Thutmose III. ${ }^{74}$

A tentative reconstruction of the so far excavated south-eastern part of the large structure, labelled Building A, is possible (Fig. 4) $:{ }^{75}$ a roofed, narrow room or corridor towards the north with a mud floor; a large central courtyard $(12.4 \times 16.2 \mathrm{~m})$ probably flanked by a lateral room or corridor towards the east. The western part of Building A is still only partly excavated, but remains of schist pavements ${ }^{76}$ and some bricks of interior walls indicate a series of small entrance rooms similar as the ones found at SAF2. ${ }^{77}$

Of particular interest within Building $\mathrm{A}$ is a storage installation in the courtyard (feature 15). ${ }^{78}$ It is half-brick thick with the inner side lined with red bricks ${ }^{79}$ and with remains of a plaster coating. Feature 15 has a minimum extension of $5.6 \mathrm{~m}$ west-east and $2.2 \mathrm{~m}$ north-south. Its western wall is set against the natural pebble in Square 4. In this area a small hole was found directly $20 \mathrm{~cm}$ above the mud bricks, dug into the gravel. Its diameter is roughly $18 \mathrm{~cm}$ and it seems to have once held a wooden beam, possibly for an entrance aid into the structure. The complete western part of feature 15 is still covered with very loose back filling of gravel, mud bricks and ceramics. Its former top seems to have been at the height of the floor level marked by the maximum of the natural pebble deposit towards the west.

72 BUDKA forthcoming $b$.

73 BUDKA forthcoming $b$.

74 BUDKA 2013, 84; BUDKA forthcoming b.

75 BUDKA 2014a, 32, fig. 8.

76 Schist slabs with mud-plaster and traces of whitewash; other examples on Sai have been documented in the magazine area in the southern part of SAV1 (AzIM 1975, 112, pl. x).

77 BUDKA 2013, 85, fig. 12; BudKA 2014a, 31.

78 BUDKA 2014a, 31, fig. 7.

79 The use of red bricks is rather rare in the New Kingdom, but it finds some parallels, e.g. in the fortress of Tell Borg: HofFmeIER 2013, 173 (for the foundation walls of the moat). 
The ceramics deriving from feature 15 are all consistently mid- $18^{\text {th }}$ Dynasty in date. Feature 15, a rectangular cellar with a vaulted roof located below the floor level, was therefore contemporaneous with Building A. Due to a number of ashy deposits, charcoal and a large number of conical bread moulds (Fig. 5), feature 15 might have been used as a bakery or a kitchen. ${ }^{80}$ Subterranean bakeries of comparable proportions, although larger in size, are known from Amarna associated with the temple complex. ${ }^{81}$

Taking all of the evidence together (location, installations, finds) it is tempting to assume a connection of Building A with Temple A. Here it is important to stress that Building A also provides a close parallel to the so-called residence SAF2. Differences concerning the columned hall and the number and size of storage facilities indicate that the latter is more likely to have been used for dwelling purposes. Both feature different types of pavements and probably had originally a second storey.

To conclude, with the results from the 2014 season it is now firmly established that Building A at SAV1 East belongs to the major remodelling of Sai during the reign of Thutmose III, being contemporaneous with Temple A and the structures in the southern part of the town including the governor's residence, SAF2, for which Building A provides a close parallel.

\subsection{SAV1 West}

In search for the town enclosure, its date, structure and stratigraphic position, a new site, SAV1 West was opened in line with the western town gate in 2014. Two trenches were laid out, Square $1(10 \times 10 \mathrm{~m})$ and Square $2(5 \times 15 \mathrm{~m})$. A western (Square 1W, $5 \times 10 \mathrm{~m})$ and north-western extension (Square 1NW, $2 \times 5 \mathrm{~m}$ ) had to be added to Square 1 because of the discovery of brick work at the edge of the trench (Fig. 6).

\section{Square 1}

With removing the upper debris levels of Square 1, it soon became clear that its western half was occupied by the remains of the New Kingdom town enclosure. Its eastern part displayed large sandy pits with much $18^{\text {th }}$ Dynasty pottery, loose mud bricks and many worked stone fragments.

In the south-western corner of Square 1 a large pit filled with mostly Christian pottery was cut into the enclosure wall. Similar holes have been dug into the brick work of the enclosure wall at SAV1 North. ${ }^{82}$ As was already observed by Azim in the 1970 s, the Sai fortification suffered from several destructions, but also restoration phases in its use-life. ${ }^{83}$ This is now confirmed by work at SAV1 West.

Despite much ancient destruction work and disturbing pits, the complete thickness of the town wall is visible (4.3-4.5m) and the foundation level has been reached in the northern part. The outline of the enclosure wall follows exactly the plan as assumed by previous surveying of French colleagues. ${ }^{84}$

80 BudKa 2014a, 31-32.

${ }^{81}$ KeMP 2012, 113, figs. 3.27-28.

82 See Doyen 2009, 17-20.

83 AzIм 1975, 122.

${ }^{84}$ See Azıм 1975, 94, pl. II, 120-122. 
A later addition to the western outline of the $18^{\text {th }}$ Dynasty wall was traceable with the extension towards the west, Square $1 \mathrm{~W}$. Secondary constructions were located outside of the New Kingdom brick work, partly reusing the bricks from the enclosure wall (Fig. 7). A layer holding much organic material, charcoal and pottery of a domestic character may indicate a small occupation spot, maybe a modest hut or shelter. Its date remains to be established, but the pottery points to a Late Christian origin.

Towards the east of the enclosure wall, thus within the New Kingdom Pharaonic town, large amounts of sandy backfilling of pits and collapsed mud bricks have been removed. At the end of the season, a level was reached in the eastern half of Square 1 where in situ New Kingdom structures appeared (Figs. 8-9). In the southeastern corner, we exposed a northsouth wall of bricks and another east-west wall, forming a rectangular structure. The gap between the north-south wall and the enclosure wall nicely corresponds to a suitable width for a "wall street" running along the enclosures wall. ${ }^{85}$ Several floor levels and ashy layers attest to a multi-period use of this small building in the south-eastern corner.

Occupation layers are also preserved in a section created by a Post-Pharaonic pit just to the east of the enclosure wall in the northern part (cfr. Fig. 8). Again, several floor levels testify that this area was in use for a considerable time span during the New Kingdom. Based on the assessment deriving from the ceramics (cfr. Fig. 14), the mud brick structures and remains in Square 1 seem to originate from the mid until the late $18^{\text {th }}$ Dynasty. No material earlier than Thutmose III was found, seemingly providing a terminus ante quem non for the building of the town wall and the visible structures belonging to the interior occupation.

\section{Square 2}

Square 2 is located in a shallow depression close to the western city gate. Some mud bricks have been visible on the surface and after cleaning a superficial deposit, the remains of the New Kingdom town enclosure were exposed in the eastern part of the trench (Fig. 6). Similar as in Square 1, the structure has been pitted in antiquity and most of the mud bricks have been removed. However, the outline of the $18^{\text {th }}$ Dynasty wall is now understood. A deep sandy pit cuts off the New Kingdom enclosure wall in the south-eastern corner. From this sandy filling, reaching down to the foundation of the town wall, comes one of the most interesting finds this season: SAV1W 532, a complete cartouche-shaped plaque with hieroglyphic inscription (see below, Fig. 10).

\section{Summary of work in SAVI West}

To conclude, excavation work in SAV1 West provided some important results: (1) The outline of the western town wall was exposed in trenches 1 and 2. Its location fits perfectly to what Azim reconstructed as the western border of the Pharaonic town. (2) A better understanding of the later destruction and also the re-use of the town wall was achieved. The destruction happened mostly in Christian times, additions and secondary structures seem to have been added later, partly using the removed brick work. (3) Despite the pitting and disturbances, very promising New Kingdom deposits have been traced within the town, east of the enclosure fig. 1).

${ }^{85}$ As attested both in the southern part (AzIM 1975, pl. VI) and in the northern part (DoyEN 2014, 368, 
wall - several phases for these structures are visible in sections of the Post-Pharaonic pits. (4) According to the finds and the pottery, there is at present no evidence of an early $18^{\text {th }}$ Dynasty activity at SAV1 West - no material pre-dating Thutmose III has been found until now. Most of it is of a mid- $18^{\text {th }}$ Dynasty date, some late $18^{\text {th }}$ Dynasty material is also present as well as few Ramesside and Napatan sherds. This seems to indicate that the enclosure wall and the adjacent Pharaonic buildings have been established during the reign of Thutmose III - corresponding to the archaeological remains at SAV1 North, SAV1 East and the southern part of the town.

\subsection{Material culture}

Objects of Egyptian type dominate the material assemblage at Sai and find many parallels at Egyptian sites in both Egypt and Nubia. At present, a total of 2397 finds from SAV1 North, 1128 pieces from SAV1 East and 602 from SAV1 West have been registered in the databases. This reflects five years of work at SAV1 North (2008-2012) under the directorship of Florence Doyen, ${ }^{86}$ two seasons at SAV1 East and one season at SAV1 West for AcrossBorders. The number of finds from SAV1 East and SAV1 West is actually much higher, but because of time restraints not all of the worked stones and tools excavated in 2014 have been documented. 850 find numbers have been used in 2014 at SAV1 West - including textiles, bones, charcoal and leather which are not integrated in the small find database but treated separately. At SAV1 East, 898 bags of finds of all types and materials have been registered in 2014.

The small find database comprises objects of all periods, thus also Post-Pharaonic material - for example, a large number of re-used sherds and figurines are of Medieval date, glass vessels and glazed wares attest to the Ottoman period on Sai and the date for the complete set of stone artefacts still has to be established.

At present, the corpus from SAV1 West is still not representative, but data from SAV1 North and SAV1 East have been compared elsewhere. ${ }^{87}$ Following a slightly modified system developed for Memphis, ${ }^{88}$ six main categories of finds have been established for Sai. Category $\mathrm{A}$ is the label for figurines and statuettes, mostly of clay and mud. Both human and animal shapes are attested in various sizes and qualities. Category B comprises personal adornment like beads and amulets. A quite diverse group is category $\mathrm{C}$, household items including large rectangular stands and basin-like installations, but also mud sealings and other objects. Tools and instruments are the largest group and have been labelled as category D. $60 \%$ of the finds from SAV1 North, 72\% from SAV1 East fall into this set, mostly stone tools like grinding stones and pounders but also re-used sherds. A small number of stone and faience vessels represents category $\mathrm{E}$, non-ceramic vessels. Category $\mathrm{F}$ is again very diverse as it comprises models, games and unidentified pieces in various materials. Finally, a number of objects cannot be classified into categories A-F - these are e.g. slag fragments attesting to production processes which are common at both areas.

${ }^{86}$ Doyen 2014, 367-375. For small finds from SAV1 North see my contribution in BudKA, Doyen 2012/2013, 182-188.

${ }^{87}$ BUDKA forthcoming $b$.

88 GIDDY 1999, passim. 


\section{Selected finds}

Other than in settlements in Egypt proper, there is an unusual small number of written evidence (seals, sealings, ostraca, dockets etc.) from the New Kingdom town of Sai. ${ }^{89}$ Whether this reflects a less important role of writing in daily life remains to be tested with future fieldwork.

Among the few inscribed pieces, three interesting objects from the town area shall be presented here because they offer (1) dating evidence and open perspectives to (2) the local cemeteries and (3) the neighbouring site Amara West. The first object falls into category F and is a cartouche-shaped plaque in mud (Fig. 10). SAV1W $532(11.4 \times 6.1 \times 3.4 \mathrm{~cm})$ bears incised hieroglyphs on the front, giving, as it seems, the name and epithet of a god. The deity is a falcon-god, possibly Horus, Horakhty or even Hauron - the group of signs in front of the god could not be read until now. The other signs probably represent a playful writing of "Lord of the Thrones of the Two Lands, numerous in beauty" (nb ns.wt t3.wj ‘̌s nfr.w)..$^{90}$ "Lord of the Thrones of the Two Lands" is a well-known epithet for Amun, Amun-Ra and Ra-Horakhty-

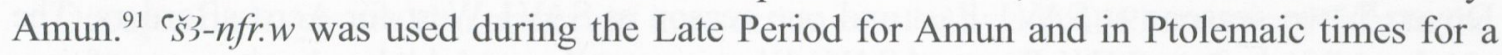
specific Horus form. ${ }^{92}$ At present, however, it cannot be excluded that the falcon of SAV1W 532 is actually associated with the king and refers to a royal epithet.

SAV1W 532 with its incised hieroglyphic cartouche reminds one of the stamped bricks attested from the early $18^{\text {th }}$ Dynasty onwards. However, it most probably held a symbolic character. It was found in the sandy pit cutting the enclosure wall in Square 2 at SAV1 West, maybe it once belonged to a foundation deposit for the town enclosure. Comparable cartoucheshaped plaques are regularly found in foundation deposits in Egypt, but most often in other materials (faience or stone) and smaller in size. According to John Weinstein, cartoucheshaped plaques are new additions to foundation deposits in the mid- $18^{\text {th }}$ Dynasty (Thutmose IV/Amenhotep III). ${ }^{93}$ This could correspond to a possible connection of SAV1W 532 with the town enclosure which can be dated to Thutmose III. However, one has to remark that the only foundation deposits attested in Upper Nubia for town walls have been found at Sesebi ${ }^{94}$ - at Sai itself, several deposits came to light in the foundations of Temple A. ${ }^{95}$ Several questions regarding SAV1W 532 must remain open for now.

Another important find from SAV1 West, unfortunately from the surface, is a fragment from the upper part a sandstone stela (Fig. 11). SAV1W $590(10.6 \times 11.2 \mathrm{~cm}$ with a width of $3.4 \mathrm{~cm}$ ) was decorated in raised relief. The lunette shows the common motif of a so-called shen-ring flanked by two wadjet eyes. Below the right wadjet eye, facing left, the presumed donor of the stela is represented: He is wearing a shoulder long wig and is offering a libation to persons facing him. Only the lotus flower of the first seated person on the left is preserved

89 See BudkA, DOYEN 2012/2013, 198-199.

90 I would like to thank Amr Gaber for suggesting the reading of " $n s . w t$ ” after a lecture in Swansea, 21/05/2014.

91 Leitz 2002B, 672, a and d.

92 See Leitz 2002A, 216a and c.

93 WeInSTEIn 1973, 94.

94 Thill 1997, 115 with references.

95 Thill 1997, 105-117. 
- it was probably a female family member, maybe the mother of the donor. However, in the $18^{\text {th }}$ Dynasty the lotus as an attribute is also well attested for men. A fragmented sandstone stela discovered in the New Kingdom cemetery at Sai shows a seated couple, with the man holding a lotus flower next to a woman embracing him (T16S21) ${ }^{96}$ According to the stylistic features of hair and costume of the donor, the stela from SAV1 West can be dated to the mid$18^{\text {th }}$ Dynasty. Close parallels are stelae datable to the reign of Thutmose III and especially Amenhotep II - for example British Museum EA 623 by the viceroy Usersatet. ${ }^{97}$ Regrettably, no text has survived on the stela fragment from SAV1 West identifying the donor by name we can safely assume that it was one of the Egyptian officials working and living on Sai, and maybe even buried on the island.

Finally, a piece probably dating to the early $19^{\text {th }}$ Dynasty, found during the French excavations in 1973 in sector SAF5 in the southern part of the town, is of interest. Thanks to recent fieldwork, it has close parallels at Amara West ${ }^{98}$ - unfortunately at both sites the pieces are fragmented and diagnostic parts are missing. SAV002, falling into category $\mathrm{C}$ of objects, is a mud object with an almost triangular section, two flat surfaces at the back and a front side showing impressions of large cartouche-shaped stamps (Fig. 12). The excavator Vercoutter proposed a function as door sealing for the piece ${ }^{99}$ and this seems indeed the most likely interpretation, corresponding also to ideas put forward for the Amara West pieces.

The impression on SAV002 has only survived in the upper part: The sun disk ( $\mathrm{Ra})$ is clearly readable as well as a seated goddess Maat, with a feather on her head, holding an ankh-sign in front of her. The lower part of the cartouche stamp is missing - it could have been Maat-[ka]-ra (Hatshepsut), [Neb]-maat-Ra (Amenhotep III) or [Men]-maat-Ra (Seti I). Hatshepsut is not yet attested on Sai Island, leaving Amenhotep III and Seti I as the most likely candidates.

Amenhotep III was very active on Sai, working on the temple for Amun-Re and leaving some inscribed blocks and other evidence. ${ }^{100}$ Seti I is known to have founded Amara West as the administrative centre of Kush, possibly shifting activities from Sai towards the new neighbouring site. Two stelae refer to military activities of the king in Kush - one from Amara West and the other set up in Sai where it was discovered during the early French excavations. ${ }^{101}$ The Nauri decree mentions an as yet unidentified fortress of the king while building activity is also attested at Sesebi. ${ }^{102}$ As the Sai stela indicates the island was not completely abandoned during the early $19^{\text {th }}$ Dynasty. At present we have little evidence for occupation- a small number of ceramics from the town and some objects from the cemeteries date to the early $19^{\text {th }}$ Dynasty, to the reigns of Seti I and Ramesses II. ${ }^{103}$ Future fieldwork

96 Minault-Gout, Thill 2012, 84 and 162.

${ }^{97}$ See http://www.britishmuseum.org/research/collection_online/collection_object_details/ collection image_gallery.aspx?assetId=237272\&objectId=116019\&partId=1 (accessed on 26/09/2014).

98 See the blog post by Chiara Salvador: http://blog.amarawest.britishmuseum.org/2014/03/08/ amarawest-2014-royal-names-in-the-house/ (accessed 09/03/2014).

99 Fieldwork diary of the French Mission, kindly made accessibly by SIAM.

100 See AzIm, Carlotti 2011-2012, 47; Gabolde 2011-2012, 137.

101 See Vercoutter 1972; EL-SaAdy 2011.

102 Cfr. el-SAady 2011, 436.

103 Cfr. BudKa 2011, 24, 29. 
might allow a better understanding of the relations between Sai and Amara West in the early Ramesside period - SAV 002 and its parallels from Amara West can be regarded as important hints for contemporaneous administrative activities at both sites.

\section{Some aspects of ceramic studies from the New Kingdom town}

One of our main objectives is to evaluate the lifestyle on Sai according to the material culture and to compare this subsequently with data from authentic Egyptian sites. Will we be able to classify typical household inventories attested at Sai as "Egyptian", "Nubian" or "Egyptianised"? Did people switch their identity and acquired different attitudes during their lifetime?

Pottery as one of the main classes of material culture in ancient settlements was of prime importance for daily activities but ceramic vessels also carry information about the identity of its user. This holds especially true for vessels related to food preparation and consumption. For Egyptian sites in Nubia it seems necessary to study ceramics associated with cooking and to make a distinction between wheel-made and hand-made pottery. ${ }^{104}$ However, both aspects are hard to categorise and complex. For example, some Nile clay pottery vessels from SAV1 North have been modelled on Egyptian types but were locally produced, sometimes with a "Nubian" influence as far as the surface treatment, production technique or decoration is concerned. The appearance of such hybrid types - Egyptian types made of Nubian fabrics, shaped by hand rather than wheel-thrown, or with a Nubian surface treatment - is very significant, but not straightforward to explain. ${ }^{105}$ It remains to be investigated whether such pots are products of a temporary or local fashion, whether they refer to the cultural identity of their users or whether they are the results of more complicated processes. All in all, they seem to attest to a complex mixture of lifestyles at Sai.

The general co-existence of Egyptian (wheel-made) and Nubian (hand-made) pottery traditions on Sai Island finds many parallels at other Upper Nubian New Kingdom sites. ${ }^{106}$ One intriguing aspect of foodways at Sai seems, however, to be unique: there is a complex fusion of Nubian and Egyptian tradition regarding the cooking pots - both imported, authentic Egyptian cooking pots thrown on the wheel ${ }^{107}$ and locally produced wheel-made copies are used side by side with Nubian-style products (hand-made pots with basketry impression or incised decoration) (Fig. 13). Residue analysis, planned in the near future, might illustrate whether a distinction was made regarding the specific food to be prepared in which pot ${ }^{108}$ and/ or if the choice was dependent on the cooking pot's user and his or her identity. ${ }^{109}$ Another possibility is that local products were simply integrated into the material culture of the Egyptian occupants and that their significance for distinguishing cultural identities is less significant. In the earliest levels at SAV1 North (levels 5 and 4), the Egyptian type of cooking pot seems to be the most common and it is gradually getting less frequent in later phases (level 3 and especially levels 2 and 1).

104 Cfr. BudKa forthcoming b.

105 Cfr. Pappa 2013, 36-37. See also BudKa forthcoming b.

106 Cfr. SMith 2002, 43-79; SMith 2003, 43-53; SPEnCER 2014, 55.

107 BudKa 2011, 26; BudKa 2012, 60.

108 Cfr. SмITH 2003, 113-124.

109 Cfr. Sмiтh 2003, 119; see also PAPPA 2013, 29-50. 
Petrographic and chemical analysis provide the tools to further differentiate between a locally produced Egyptian style, wheel-made vessels and a real Egyptian import in Nile clay. Instrumental NAA was already applied to material from Askut, Hannek and Tombos; ${ }^{110}$ AcrossBorders started its ongoing analysis in 2013, conducted by Johannes Sterba and Giulia d'Ercole. First results revealed subgroups for the Nile clay fabrics which correspond to (a) locally made Nubian style vessels, (b) locally made Egyptian style vessels and (c) imported Egyptian style vessels. The latter find close macroscopic and petrographic parallels at Elephantine. Eventually it might therefore be possible to identify the exact production place for the real Egyptian imports found on Sai Island.

From Thutmoside times onwards, a high variability of ceramic wares can be observed, including imports from Egypt, the Western Oases, Canaan and the Aegean world (Fig. 14). ${ }^{111}$ The corpus is very similar to material from Elephantine during the $18^{\text {th }}$ Dynasty and early Ramesside period. Is it possible to connect these "luxury wares" with the occupants of Sai? Was it perhaps appealing for the Egyptians living on Sai to be perceived by the local inhabitants as cosmopolitan Egyptians? Was the range of painted ceramic vessels, so different from the Nubian pottery style, used to demonstrate the sophistication of the officials? Or was it perhaps important for an Egyptian himself, living abroad, to surround himself with things and objects evoking the international sphere from cities like Memphis and Thebes back home? Or maybe this holds true for Egyptianised Nubians working for the Egyptian administration and living in an Egyptian-style town as well?

Apart from the attractive, but not provable idea of an active role of ceramic vessels in creating "Pharaonic lifestyle" on Sai Island, ${ }^{112}$ it is also possible that imported and nicely decorated vessels were regarded, especially in Upper Nubia and maybe by (Egyptianised) Nubians, as simply pretty "knick-knacks with exotic cachet." ${ }_{113}$ However, as objects never have one single meaning, it remains to be tested how the entire ceramic corpus of New Kingdom Sai contributes to the reconstruction of life styles on the island.

\subsection{The Occupants of Sai}

The question of the identity of the occupants of the Sai Island New Kingdom town is crucial for the project AcrossBorders. Who were the inhabitants as far as their cultural identity is concerned: Egyptians, Egyptianised Nubians or a mix of both? At present, it is still too early to provide conclusive answers.

In the forthcoming years, the AcrossBorders project aims to deepen this line of research by analysing all available sources and the complete set of evidence. Even with the difficulties in connecting material remains with cultural identities, we will investigate whether the identities projected by the occupants of Sai are consistent (or different) in life and death, thus a detailed comparison between the material found in the town and in the cemeteries will be undertaken. Even if funerary objects reflect contemporaneous Egyptian style, the individuals with Egyptian

10 Carrano et al. 2008, 35-61.

111 Cfr. Budka, Doyen 2011/2012, 193-196, fig. 23.2.

112 Cfr. Barrett 2009, 227.

113 BARRETT 2009, 226. 
names and titles might still be of Nubian origin. ${ }^{114}$ For this purpose we will resume work in the large New Kingdom cemetery SAC 5, ${ }^{115}$ aiming to analyse also the human remains. Human skeletal material holds much potential and is essential for questions of identities and migration, as was illustrated by studies at Tombos. ${ }^{116}$ Only in combining the evidence from the town and the cemeteries, especially the material culture and inscribed objects, there is much potential that we will be able to trace the occupants of Sai in the upcoming years - at present, all of them appear as Egyptian/Egyptianised officials who have been buried with statues, scarabs, shabtis and other objects.

\section{Conclusion and Outlook}

To conclude, archaeological findings of recent years illustrate that the "re-conquest" of Nubia and the establishing of Egyptian authority in Upper Nubia was a long process with considerable changes. Large scale Pharaonic building activity seems not to be attested before Thutmose III: only then, with the Kerma kingdom overthrown, the temple towns/mnn.w and large stone temples for gods were realised. Beginning with the reign of Thutmose III, there is also abundant evidence for viceroys, mayors and other officials in Upper Nubia; the system of the jdnw $n W 3 w 3 . t$ and $K 3 \check{s}$ was established soon after. ${ }^{117}$

Life and living conditions in Nubia and, as present here, on Sai Island have changed markedly in character from the reign of Ahmose Nebpehtyra to Thutmose III. By the time of Thutmose III, the second generation of witnesses of the first Egyptians campaigns were living at the sites. These individuals had therefore another relationship with the Egyptians and there was more time for them to be fully integrated into the Egyptian power structure and administrative system. This is reflected in the pottery which attests to the full integration of the town on Sai within Egyptian international trade routes of the second half of the $18^{\text {th }}$ Dynasty. ${ }^{118}$ I would like to propose that the evolution of the Pharaonic town of Sai, as preliminarily and fragmentarily as it is currently understood, actually reflects the phases of Egyptian involvement in Nubia:

1. Ahmose Nebpehtyre led several campaigns against the kingdom of Kerma in Nubian territory, reaching as far as the Third Cataract. Ahmose and his troops probably set up a small camp on Sai Island with several storage installations. The material culture is primarily Egyptian, but with a Kerma presence. Nothing indicates that the Egyptians were already involved on Sai on a permanent basis and with large scale building activities. The Egyptian presence in Kush was as limited as it is reflected in the missing data for a sophisticated administration like it is attested in Wawat.

2. Thutmose I managed to go further upstreams, as far as Kurgus, and he founded several fortified towns in Nubia. Unfortunately, archaeological proof for the identification of these sites is still lacking. At Sai, no enclosure wall is traceable during this period.

\footnotetext{
114 Cfr. Minault-Gout, Thill 2012, 415.

115 Minault-Gout, Thill 2012, passim; see also BudKa 2014b.

116 Buzon 2008, 165-182; SMith, Buzon 2014, 431-442.

117 Cfr. Мовкот 2013, 925-926.

118 See BudKa 2011, 31.
} 
Possibly the camp set up by Ahmose continued and storage facilities were used - a full account of the site during the reign of Thutmose I is not possible. The material culture is primarily Egyptian, but with a Kerma presence indicating close relations between Egyptians and Nubians. The phase of the Egyptianisation of Kush seems to have started. ${ }^{119}$

3. After several contributions by Thutmose II and Hatshepsut, ${ }^{120}$ Thutmose III succeeded in overthrowing the Kingdom of Kush. The mnn.w at Sai was equipped with an enclosure wall and extended to a large scale site of administrative importance, including a stone temple for Amun-Ra built in several phases. Current fieldwork has highlighted that by the reign of Thutmose III, Sai had become one of the most important Egyptian centres in Upper Nubia. The material culture gets more diverse, international and compares to Egyptian sites like Elephantine. There is still a mixture of Nubian and Egyptian ceramics, but locally made Egyptian style vessels prevail. Hybrid types of vessels indicate a complex entanglement of the Nubian with the Egyptian culture. The time of Thutmose III was the first heyday of Egyptian involvement in Kush.

4. Amenhotep II, Thutmose IV and Amenhotep III continued Pharaonic building activities in Upper Nubia with a focus on temples and the gold of Kush. On Sai Island, the Nubian component in the material culture is by this time much faded - presumably, the indigenous elements have been largely Egyptianised and are difficult to detect in the archaeological record. Kush was under the same Egyptian influence as Wawat.

The first seasons of fieldwork of AcrossBorders have highlighted not only major aspects of the diachronic history of Sai, but it also allows some thoughts about the specific lifestyle within the New Kingdom town. Other than drawing artificial border lines between Egyptians and Nubians and their respective lifestyle, the aim should be to reconstruct social, economic and cultural identities at the local level. Such identities are changing, interacting and merging with each other and will allow a more direct approach to diverse aspects of life than a stereotype perspective derived primarily from textual references. ${ }^{121}$

\section{Acknowledgements}

Research for this paper was conducted within the framework of the author's START-prize of the Austrian Science Fund: Y615-G19 and the ERC Starting Grant project AcrossBorders, Grant Agreement no. 313668. All fieldwork on Sai Island is undertaken under the auspices of the Sai Island Archaeological Mission directed by Didier Devauchelle (Charles-deGaulle - Lille 3 University, UMR 8164 HALMA-IPEL) and in association with the National Corporation for Antiquities and Museums in Khartoum (Sudan). I am especially grateful to Abdelrahman Ali (Director General), El Hassan Ahmed (Director of Fieldwork), Huda Magzoub Elbashir (our site inspector in 2013 and 2014) and to all local and international team members, especially to Erich Draganits and Giulia D’Ercole. We are very grateful to Johannes

119 See also the evidence from Kerma, Valbelle 2014, 107.

120 Cfr. Bonnet 2012, 71; Valbelle 2005, 33-50.

121 See in more detail: BUDKA forthcoming $b$. 
Sterba (Institute of Atomic and Subatomic Physics, Vienna) for his cooperation regarding the iNAA of ceramic samples from Sai (which will be published elsewhere). Special thanks are due to W. Vivian Davies for kindly sharing thoughts about the $18^{\text {th }}$ Dynasty presence on Sai and in Nubia. The written English of this paper was kindly improved by Kenneth Griffin.

\section{Bibliography}

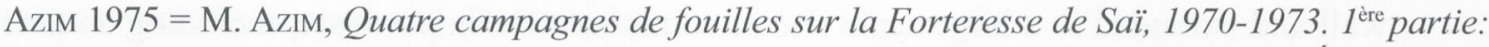
l'installation pharaonique, «Cahiers de Recherches de l'Institut de Papyrologie et d'Égyptologie de Lille» 3, 1975, 91-125.

Azim, Carlotti 2011-2012 = M. Azim, J.-F. Carlotti, Le temple A de l'île de Saï et ses abords, «Cahiers de Recherches de l'Institut de Papyrologie et d'Égyptologie de Lille» 29, 2011-2012, 11-63.

Barrett $2009=$ C. E. Barrett, The Perceived Value of Minoan and Minoanizing Pottery in Egypt, «Journal of mediterranean archaeology» 22, 2009, 211-234.

BINDER $2011=$ M. BINDER, The 10th-9th century BC-New Evidence from Cemetery C of Amara West, «Sudan \& Nubia» 15, 2011, 39-53.

BONNET $2012=\mathrm{C}$. BONNET, Les grands monuments égyptiens et nubiens du début de la XVIII dynastie sur le site de Doukki Gel (Kerma), «Bulletin de l'Institut Français de l'Archéologie Orientale» 112, 2012, 57-75.

Bonnet $2014=\mathrm{C}$. Bonnet (with the collaboration of D. VALbeLle), La ville de Kerma. Une capitale nubienne au sud de l'Égypte, Paris 2014.

Breasted 1908 = J. H. Breasted, Second Preliminary Report of the Egyptian Expedition, «The American Journal of Semitic Languages» 25, 1908, 1-110.

BudKA $2005=$ J. BudKA, The Third Cataract - Its Historical and Political Importance According to Royal and Private Graffiti at Tombos, in A. AmentA, M. M. Luiselli, M. N. Sordi (ed.), L'Acqua nell'antico Egitto. Vita, rigenerazione, incantesimo, medicamento. Proceedings of the First International Conference for Young Egyptologists, Italy, Chianciano Terme, October 15-18, 2003, Roma 2005, 107-115.

Budka 2011 = J. Budka, The early New Kingdom at Sai Island: Preliminary results based on the pottery analysis (4 $4^{\text {th }}$ Season 2010), «Sudan \& Nubia» 15, 2011, 23-33.

BudKa 2013 = J. BudKa, Die 18. Dynastie auf Sai Island (Nordsudan) - neue Puzzlesteine als Ergebnisse der Feldkampagne 2013, «Sokar» 26, 2013, 78-87.

Budka $2014=$ J. Budka, Neues zur Tempelstadt der 18. Dynastie auf Sai Island (Nordsudan) Ergebnisse der Feldkampagne 2014, «Sokar» 28, 2014, 28-37.

BudKa 2012 = J. BudKa, Review of Anne Minault-Gout and Florence Thill, Saï II. Le cimetière des tombes hypogées du Nouvel Empire (SAC5), FIFAO 69, Cairo 2012, «Methodos» [online] 14, [http://methodos.revues.org/3760].

BUdKA 2014-2015 = J. BUdKA, The Egyptian "re-conquest of Nubia" in the New Kingdom - some thoughts on the legitimization of Pharaonic power in the South, in F. COPPEnS, J. JANÁK, H. Vymazaloví (eds), 7. Tagung zur Königsideologie. Royal versus Divine Authority, Acquisition, Legitimization and Renewal of Power, Wiesbaden [due 2014-2015], forthcoming a.

BudKa 2015 = J. BudKa, Life in the New Kingdom town of Sai Island: some new perspectives, in N. Spencer, M. Binder, A. Stevens (ed.), Nubia in the New Kingdom: Lived experience, pharaonic control and indigenous traditions, British Museum Publications on Egypt and Sudan 2, Leuven [due 2015], forthcoming b.

BudKa $2015=\mathrm{J}$. BudKa, Palaces in so-called Nubian temple towns: A reassessment, «Egypt \& Levant» 24 [due 2015], forthcoming c. 
BudKa, F. Doyen 2012/2013 = J. BudKa, F. Doyen, Living in New Kingdom towns in Upper Nubia-New evidence from recent excavations on Sai Island, «Egypt \& Levant»22/23, 2012/2013, 167-208.

Buzon $2008=$ M. R. Buzon, A Bioarchaeological Perspective on Egyptian Colonialism in the New Kingdom, «Journal of Egyptian Archaeology» 94, 2008, 165-182.

Carrano 2008 = J. Carrano et al., A Chemical Analysis of Ancient Nubian- and Egyptian-Style Ceramics: Evaluating the Substance of Style, «Mitteilungen des Deutschen Archäologischen Instituts, Abteilung Kairo» 64, 2008, 35-61.

Darnell 2013 = J. C. Darnell, A Bureaucratic Challenge? Archaeology and Administration in a Desert Environment (Second Millennium B.C.E.), in J. C. Moreno GarCía (ed.), The Administration of Egypt, Handbuch der Orientalistik 104, Leiden 2013, 785-830.

DAVIES 1998 = W. V. DAVIES, New fieldwork at Kurgus. The Pharaonic Inscriptions, «Sudan \& Nubia» 2, 1998, 26-30.

Davies 2005 = W. V. Davies, Egypt and Nubia. Conflict with the Kingdom of Kush, in C. H. Roehrig (ed), Hatshepsut: From Queen to Pharao, New York 2005, 49-56.

DAVIES $2008=\mathrm{W}$. V. Davies, Tombos and the Viceroy Inebny/Amenemnekhu, «British Museum Studies in Ancient Egypt and Sudan» 10, 2008, 39-63.

DAVIES 2009 = W. V. DAvIES, The British Museum epigraphic survey at Tombos: the stela of Usersatet and Hekaemsasen, «British Museum Studies in Ancient Egypt and Sudan» 14, 2009, 25-50.

DAVIES $2010=$ W. V. DAVIES, Reneseneb and Sobeknakht of Elkab: the genealogical data, in M. MARÉE (ed), The Second Intermediate Period (Thirteenth-Seventeenth Dynasties). Current Research, Future Prospects, Orientalia Lovaniensia Analecta 192, Leuven, Paris and Walpole, MA 2010, 223-240.

DAVIEs 2014 = W. V. Davies, The Egyptians in Kush: the discoveries of F W Green, «Sudan \& Nubia» 18,2014 , in press.

Devauchelle, Doyen 2009 = D. Devauchelle, F. Doyen, Retour à l'Île de Saï (Soudan, 2006-2009), «Bulletin de la Société française d'Égyptologie» 175, 2009, 29-49.

Doyen 2009 = F. Doyen, The New Kingdom Town on Sai Island (Northern Sudan), «Sudan \& Nubia» $13,2009,17-20$.

Doyen 2014 = F. Doyen, Sai Island New Kingdom Town (Northern Sudan): $3^{\text {rd }}$ and $4^{\text {th }}$ Seasons (20092010), in J. Anderson, D. Welsby (ed.), The Fourth Cataract and Beyond. Proceedings of the $12^{\text {th }}$ International Conference for Nubian Studies, British Museum Publications on Egypt and Sudan 1, Leuven 2014, 367-375.

Edwards 2012 = D. N. Edwards, The Third-Second Millennia BC. Kerma and New Kingdom Settlement, in D. N. Edwards (ed.), Archaeology of a Nubian frontier. Survey on the Nile Third Cataract, Sudan, Leicester 2012, 59-87.

Fisher 2012 = M. M. Fisher, The History of Nubia, in M. M. Fisher, P. Lacovara, S. Ikram, S. D'Auria (ed.), Ancient Nubia. African Kingdoms on the Nile, Cairo 2012, 10-44.

GABOLDE 2011-2012 = L. GABOLDE, Réexamen des jalons de la présence de la XVIII ${ }^{e}$ dynastie naissante à Saï, «Cahiers de Recherches de l'Institut de Papyrologie et d'Égyptologie de Lille» 29, 20112012, 115-137.

Geus 2004 = F. Geus, Sai, in D. WelsBy, J. Anderson (eds), Sudan. Ancient treasures. An exhibition of recent discoveries from the Sudan National Museum, London 2004, 114-116.

GidDy 1999 = L. Giddy, The Survey of Memphis II. Kom Rabica: the New Kingdom and Post-New Kingdom objects, Egypt Exploration Society Excavation Memoir 64, London 1999.

Gratien 1986 = B. Gratien, Saï I. La nécropole Kerma, Paris 1986. 
Gratien 1995 = B. Gratien, Gism el-Arba, un habitat Kerma. Les niveaux tardifs, "Cahiers de Recherches de l'Institut de Papyrologie et d'Égyptologie de Lille» 17/2, 1995, 5-65.

Gratien et al. 2003 = B. Gratien, S. Marchi, O. Thuriot, J.-M. Willot, Gism el-Arba, habitat 2. Rapport préliminaire sur un centre de stockage Kerma au bord du Nil, «Cahiers de Recherches de 1'Institut de Papyrologie et d'Égyptologie de Lille» 23, 2003, 29-43.

Gratien et al. 2003-2008 = B. Gratien, S. Marchi, D. Sys, R.-P. Dissaux, Gism el-Arba-Habitat 2, Campagne 2005-2006, «Kush» 19, 2003-2008, 21-35.

Graves 2011 = C. Graves, Egyptian imperialism in Nubia c. 2009 - 1191 BC, MPhil thesis, University of Birmingham 2011 [http://etheses.bham.ac.uk/1389/].

HofFMeIER 2013 = J. K. HofFMEIER, Reconstructing Egypt's Eastern Frontier Defense Network in the New Kingdom (Late Bronze Age), in F. Jesse, C. Vogel (ed.), The Power of Walls - Fortifications in Ancient Northeastern Africa. Proceedings of the International Workshop held at the University of Cologne, $4^{\text {th }}-7^{\text {th }}$ August 2011, Colloquium Africanum 5, Cologne 2013, 163-194.

Kemp 1972 = B. J. Kemp, Fortified towns in Nubia, in P. J. Ucko, R. Tringham, G. W. Dimbledy (ed.), Man, Settlement and Urbanism, London 1972, 651-656.

Kemp 1972 = B. J. Kemp, Temple and Town in Ancient Egypt, in P. J. Ucko, R. Tringham, G. W. Dimbledy (ed.), Man, Settlement and Urbanism, London 1972, 657-680.

Kemp 2012 = B. J. Kemp, The City of Akhenaten and Nefertiti. Amarna and its people, Cairo 2012.

Klemm, D. Klemm 2013 = R. Klemm, D. Klemm, Gold and Gold Mining in Ancient Egypt and Nubia. Geoarchaeology of the Ancient Gold Mining Sites in the Egyptian and Sudanese Eastern Deserts, Natural Science in Archaeology, Heidelberg, New York, Dordrecht, London 2013.

Lacovara 2012 = P. Lacovara, The Land of Nubia, in M. M. Fisher, P. Lacovara, S. Ikram, S. D'Auria (ed.), Ancient Nubia. African Kingdoms on the Nile, Cairo 2012, 5-9.

LeITZ 2002 = C. LeITZ et al., Lexikon der ägyptischen Götter und Götterbezeichnungen, vol. II, Orientalia Lovaniensia Analecta 111, Leuven 2002.

LeItz 2002 = C. LeITz et al., Lexikon der ägyptischen Götter und Götterbezeichnungen, vol. III, Orientalia Lovaniensia Analecta 112, Leuven 2002.

Minault-Gout, Thill 2012 = A. Minault-Gout, F. Thill, Saï II. Le cimetière des tombes hypogées du Nouvel Empire (SAC5), Fouilles de l'Institut Français d'Archéologie Orientale 69, Cairo 2012.

Mовкот $2013=$ R. Мовкот, From conquered to conqueror: the organization of Nubia in the New Kingdom and the Kushite administration of Egypt, in J. C. Moreno García (ed.), The Administration of Egypt, Handbuch der Orientalistik 104, Leiden 2013, 911-963.

MORRIS $2005=\mathrm{E}$. F. Morris, The architecture of imperialism. Military bases and the evolution of foreign policy in Egypt's New Kingdom, Probleme der Ägyptologie 22, Leiden/Boston 2005.

Müller 2013 = I. Müller, Die Verwaltung Nubiens im Neuen Reich, Meroitica 18, Wiesbaden 2013.

O'Connor 1997 = D. O'Connor, The Hyksos Period in Egypt, in E. D. Oren (ed.), The Hyksos: New Historical and Archaeological Perspectives, University Museum Monographs 96, Symposium Series 8, Philadelphia, Pennsylvania 1997, 45-67.

PAPPA 2013 = E. PAPPA, Postcolonial baggage at the end of the road: How to put the genie back into its bottle and where to go from there, "Archaeological Review from Cambridge» 28.1, 2013, 29-50.

Van Pelt 2013 = W. P. Van Pelt, Revising Egypto-Nubian relations in New Kingdom Lower Nubia: From Egyptianization to cultural entanglement, «Cambridge Archaeological Journal» 23, 2013, 523-550.

EL-SAady 2011 = H. el-SaAdy, Egypt in Nubia during the Reign of Seti I, in M. Collier, S. Snape (ed.), Ramesside Studies in Honour of K.A. Kitchen, Bolton 2011, 433-437. 
SchifF Giorgini 1965 = M. Schiff Giorgini, Soleb I: 1813-1963, Florence 1965.

Schiff Giorgini $1971=$ M. Schiff Giorgini, Soleb II: Les nécropoles, Florence 1971.

SChifF GIorgini 1998 = M. Schiff Giorgini, Soleb V: Le temple. Bas reliefs et inscriptions, Cairo 1998. Schiff Giorgini 2002 = M. Schiff Giorgini, Soleb III: Le temple. Description, Cairo 2002.

SCHIFF Giorgini $2003=$ M. Schiff Giorgini, Soleb IV: Le temple. Plans et photographies, Cairo 2003.

Seidlayer 2006 = S. J. Seidlmayer, Der Beitrag der Gräberfelder zur Siedlungsarchäologie Ägyptens, in E. Czerny et al. (ed.), Timelines 1. Studies in Honour of Manfred Bietak, Orientalia Lovaniensia Analecta 149, Leuven, 2006, 309-316.

Sмітн $1995=$ S. T. Sмітн, Askut in Nubia. The Economics and Ideology of Egyptian Imperialism in the Second Millennium B.C., London and New York 1995.

SмІтн $2002=$ S. T. Sмітн, Pots and politics: Ceramics from Askut and Egyptian colonialism during the Middle through New Kingdoms, in C. A. Redmount, C. A. Keller (ed.), Egyptian Pottery, Proceedings of the 1990 Pottery Symposium at the University of California, University of California Publications in Egyptian Archaeology 8, Berkeley 2002, 43-79.

Sмітн $2003=$ S. T. Sмітн, Wretched Kush. Ethnic identities and boundaries in Egypt's Nubian Empire, London and New York 2003.

Sмітн 2014 = S. T. Sмітн, Editorial essay: Nubia, coming out of the shadow of Egypt, «Journal of Ancient Egyptian Interconnections» 6:1, 2014, 1-4.

Sмітн 2014 = S. T. Sмітн, M. Buzon, Colonial entanglements: "Egyptianization" in Egypt's Nubian Empire and the Nubian Dynasty, in D. Welsby, J. R. Anderson (ed.), Proceedings of the 12th International Conference for Nubian Studies, British Museum Publications on Egypt and Sudan 1, Leuven 2014, 431-442.

Spence, P. J. Rose 2009 = K. SPence, P. J. Rose, Fieldwork at Sesebi, 2009, «Sudan \& Nubia» 13, 2009, 38-46.

Spence, P. J. Rose 2011 = K. Spence, P. J. Rose et al., Sesebi 2011, «Sudan \& Nubia» 15, 2011, 34-39.

SPENCER $2009=$ N. SPENCER, Cemeteries and late Ramesside suburb at Amara West, «Sudan \& Nubia» $13,2009,47-61$.

SPENCER 2010 = N. SPENCER, Nubian architecture in an Egyptian town?, «Sudan \& Nubia» 14, 2010, 15-24.

SPENCER $2014=$ N. SPencer, Creating and re-shaping Egypt in Kush: Responses at Amara West, «Journal of Ancient Egyptian Interconnections» 6:1, 2014, 42-61.

SPENCER 2014= N. SPENCER, Amara West: considerations on urban life in occupied Kush, in D. WelsBy, J. R. Anderson (ed.), Proceedings of the 12th International Conference for Nubian Studies, British Museum Publications on Egypt and Sudan 1, Leuven 2014, 457-485.

SPENCER et al. 2012 = N. SPEnCER, M. Macklin, J. WoOdWARD, Reassessing the Abandoment of Amara West: The impact of a changing Nile?, «Sudan \& Nubia»16, 2012, 37-47.

Spencer et al. 2014 = N. Spencer, A. Stevens, M. Binder (ed.), Amara West. Living in Egyptian Nubia, London 2014.

Stevens $2014=$ A. Stevens, The desert beyond, in N. Spencer, A. Stevens, M. Binder (ed.), Amara West. Living in Egyptian Nubia, London 2014, 22.

ThILl 1997 = F. Thill, Les premiers dépôts de fondation de Sä̈, «Cahiers de Recherches de l'Institut de Papyrologie et d'Égyptologie de Lille» 17/2, 1997, 105-117.

TÖRÖK 2009 = L. TÖRÖK, Between Two Worlds: The Frontier Region between Ancient Nubia and Egypt $3700 B C$ - $500 A D$, Probleme der Ägyptologie 29, Leiden 2009.

Valbelle 2005 = D. Valbelle, Hatchepsout en Nubie, «Bulletin de la Société française d'Égyptologie» $167,2005,33-50$ 
Valbelle 2012 = D. Valbelle, Comment les Égyptiens du début de la XVIII ${ }^{e}$ dynastie désignaient les Kouchites et leurs alliés, «Bulletin de l'Institut Français de l'Archéologie Orientale» 112, 2012, 447-464.

VALbelle $2014=$ D. VAlbelle, International relations between Kerma and Egypt, in J. Anderson, D. Welsby (ed.), The Fourth Cataract and Beyond. Proceedings of the $12^{\text {th }}$ International Conference for Nubian Studies, British Museum Publications on Egypt and Sudan 1, Leuven 2014, 103-109.

Vercoutter 1956 = J. Vercoutter, New Egyptian Texts from the Sudan, «Kush» 4, 1956, 66-82.

Vercoutter 1959 = J. Vercoutter, The Gold of Kush, «Kush» 7, 1959, 120-153.

Vercoutter 1972 = J. Vercoutter, Une campagne militaire de Séti en Haute Nubie. Stèle de Saï S. 579, «Revue d’Égyptologie» 24, 1972, 201-208.

Vercoutter 1973 = J. Vercoutter, La XVIII dynastie à Sä̈ et en Haute-Nubie, «Cahiers de Recherches de l'Institut de Papyrologie et d'Égyptologie de Lille» 1, 1973, 7-38.

WeinsteIn 1973 = J. WeinsteIn, Foundation deposits in Ancient Egypt, Dissertation, University of Pennsylvania 1973.

Zibelius-Chen 2013 = K. Zibelius-Chen, Nubien wird ägyptische Kolonie, in St. Wenig, K. ZibeliusCHEN (ed.), Die Kulturen Nubiens - ein afrikanisches Vermächtnis, Dettelbach 2013, 135-155. 


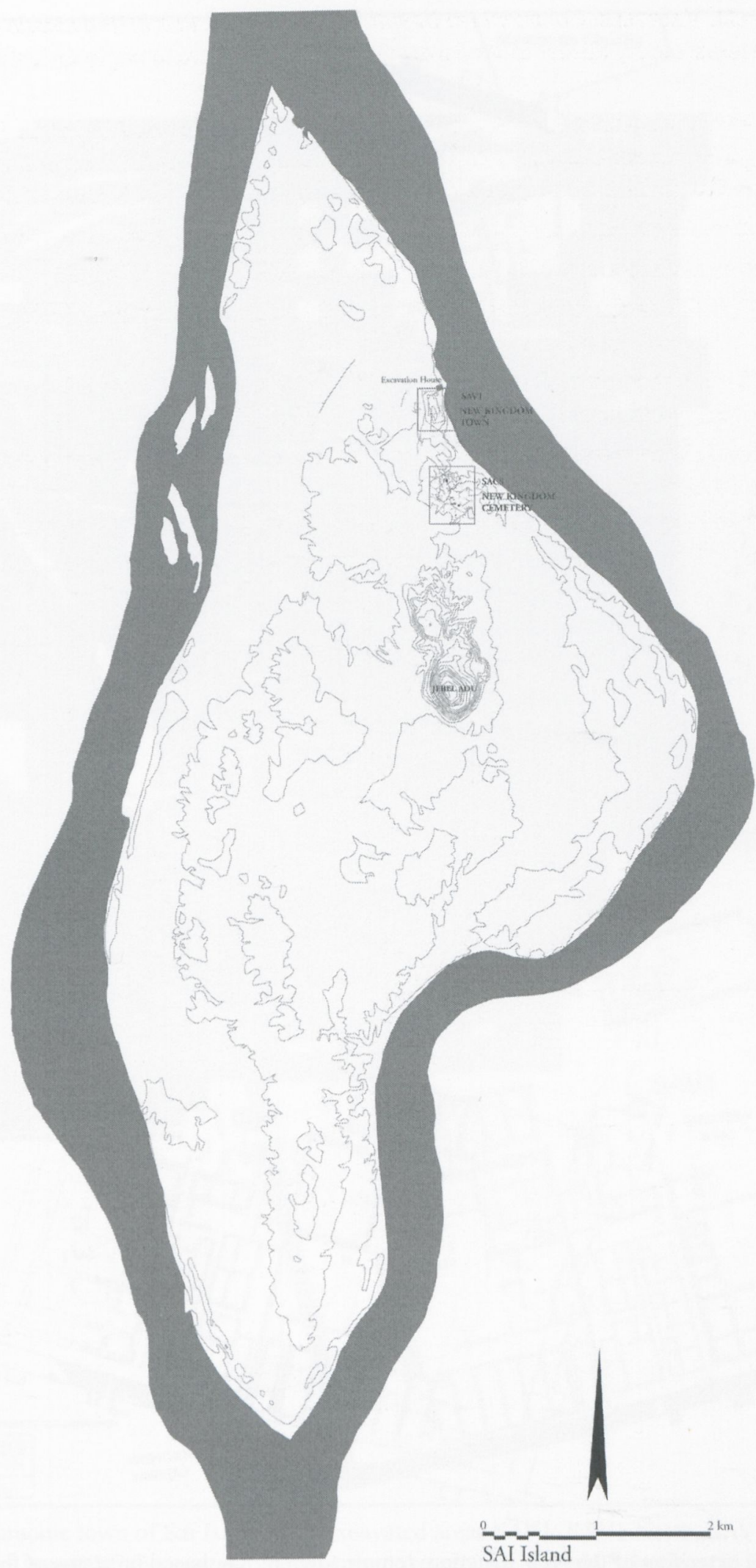

Fig. 1 - Sai Island with location of the Pharaonic town SAV1 on its eastern side. C) AcrossBorders 2014. 


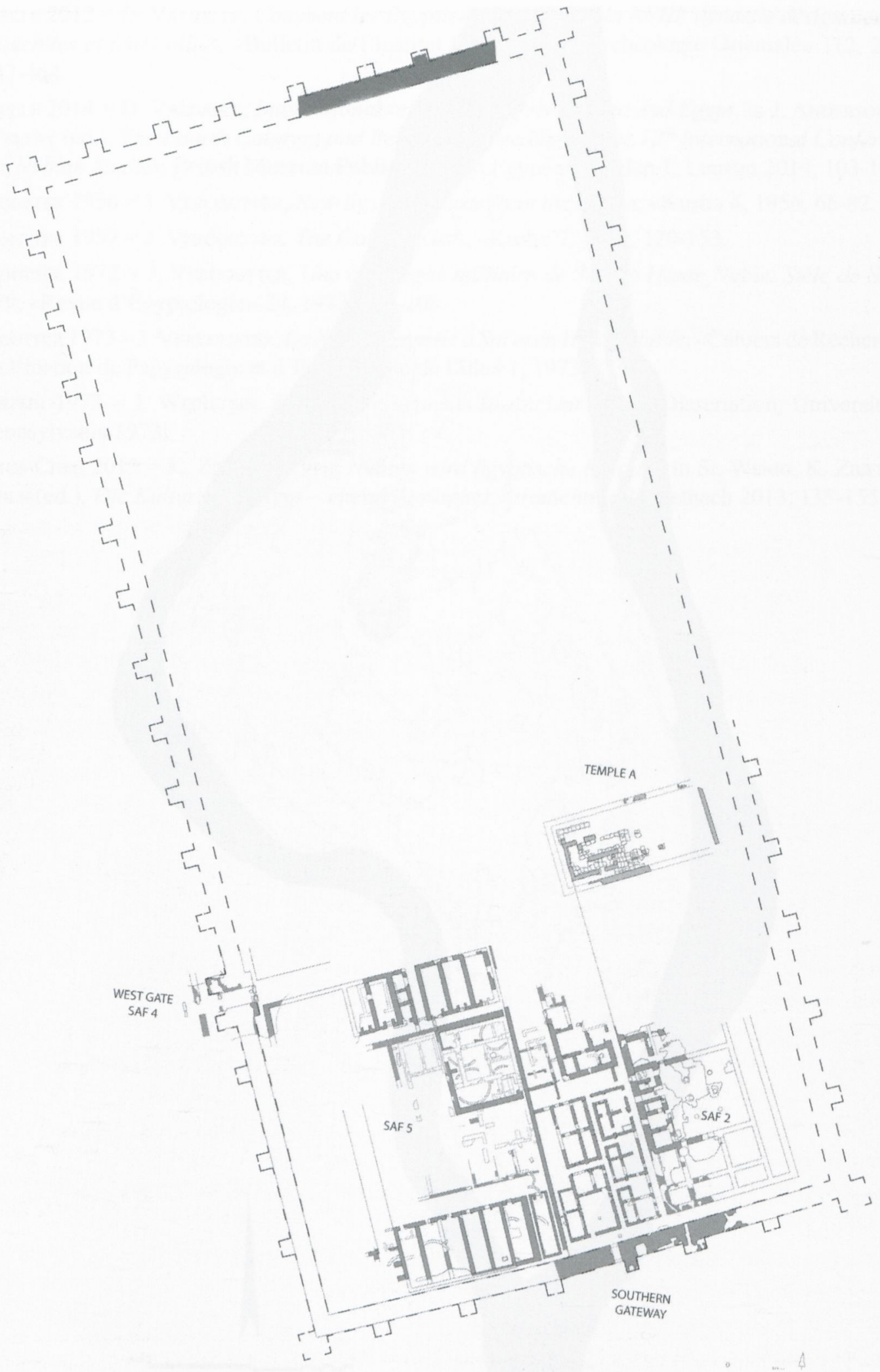

Fig. 2 - Estimated extension of the New Kingdom temple town of Sai, based on status of fieldwork in 2014 with a hypothetical reconstruction of the eastern side. Illustration: Elke Schuster, (c) AcrossBorders 2014. 


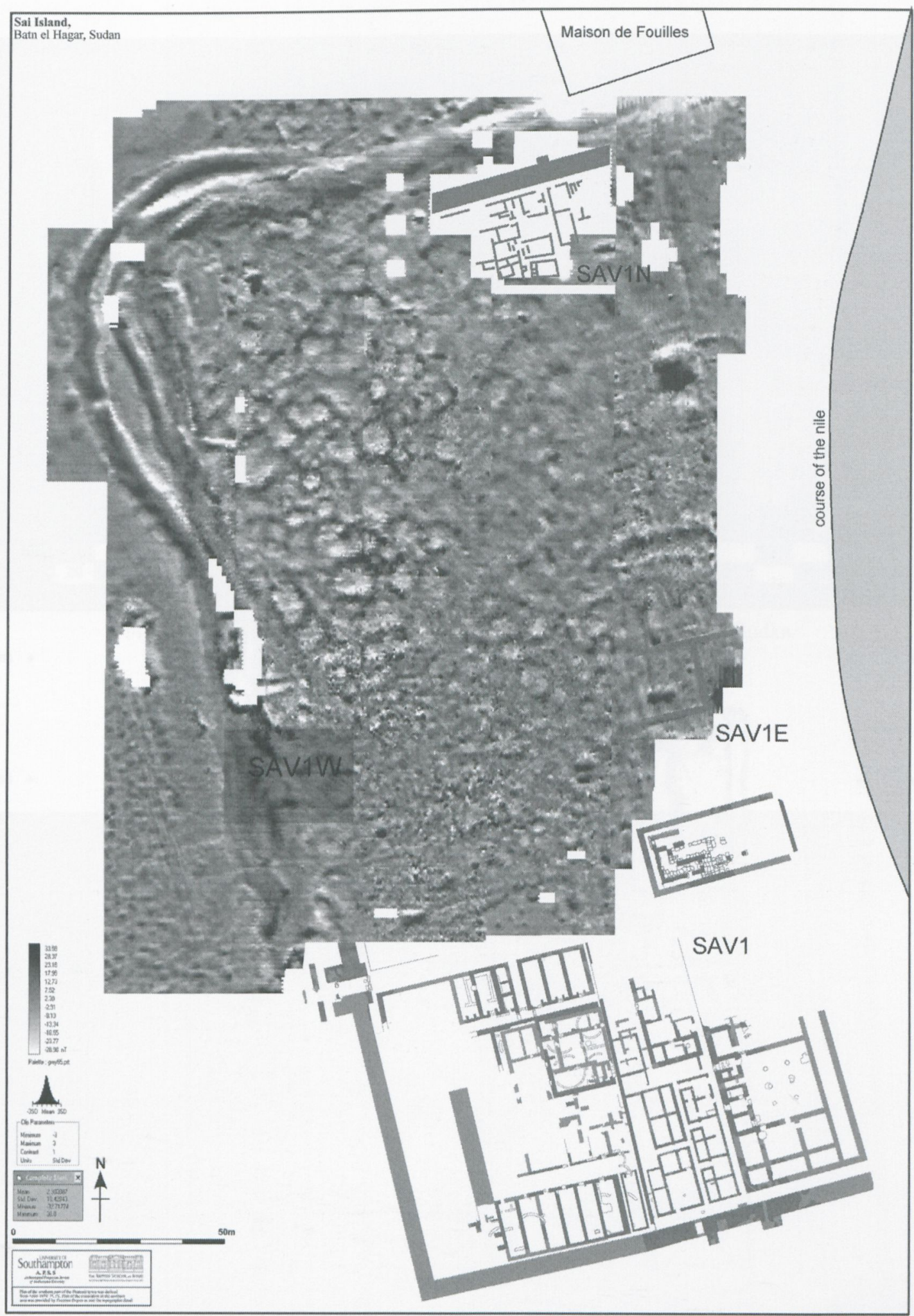

Fig. 3 - The Pharaonic town of Sai Island with excavated areas SAV1, SAV1 North, SAV1 East and SAV1 West. Greyscale image of the magnetometer survey results by British School at Rome/University of Southampton), SAV1 from Adenstedt 2013 after Azim 1975. (c) AcrossBorders 2014. 


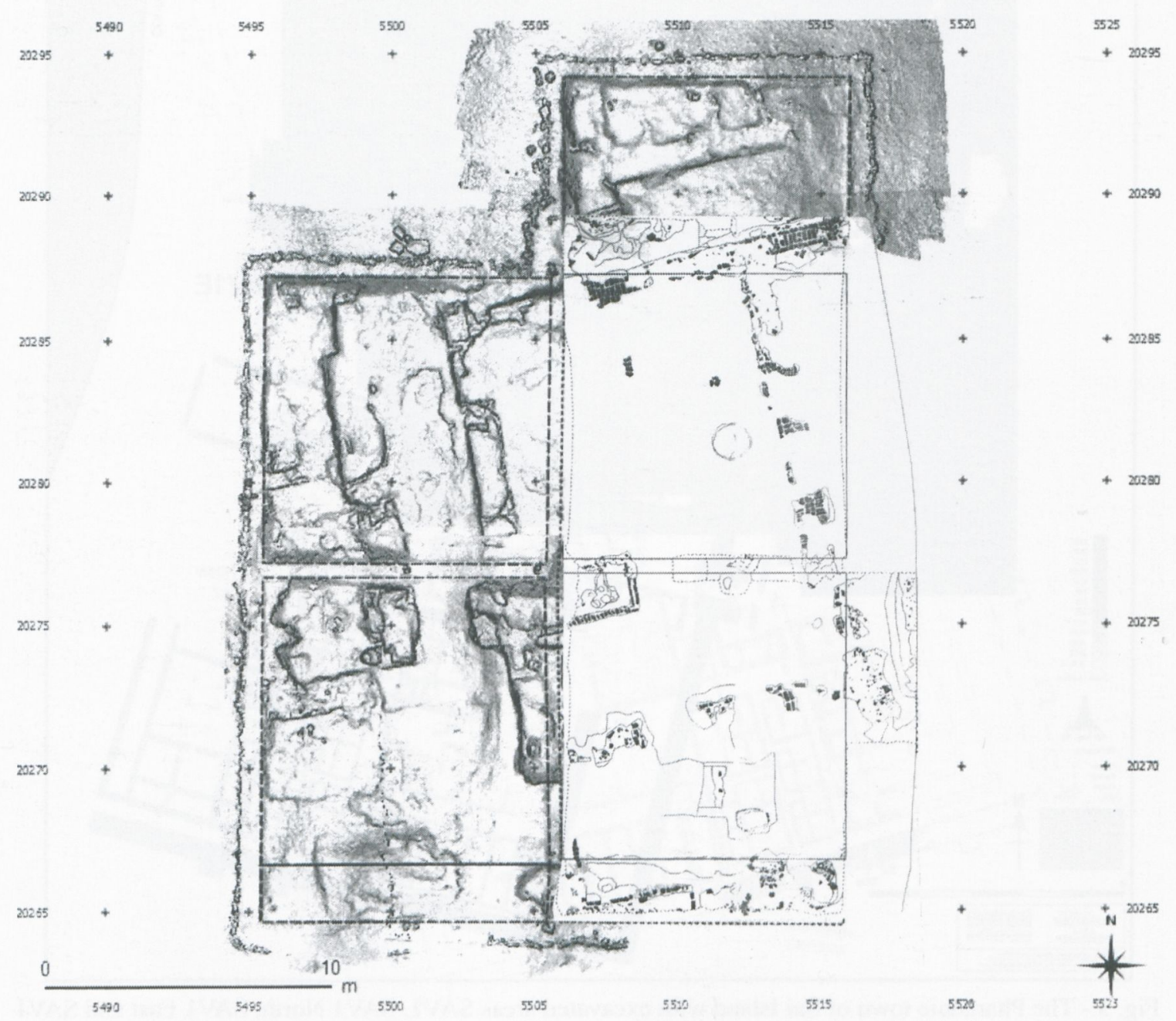

Fig. 4 - Excavations squares at SAV1 East with remains of Building A; combined illustration of 3D surface model (Martin Fera 2014) and ground plan of East part (Julia Budka). (C) AcrossBorders 2014. 


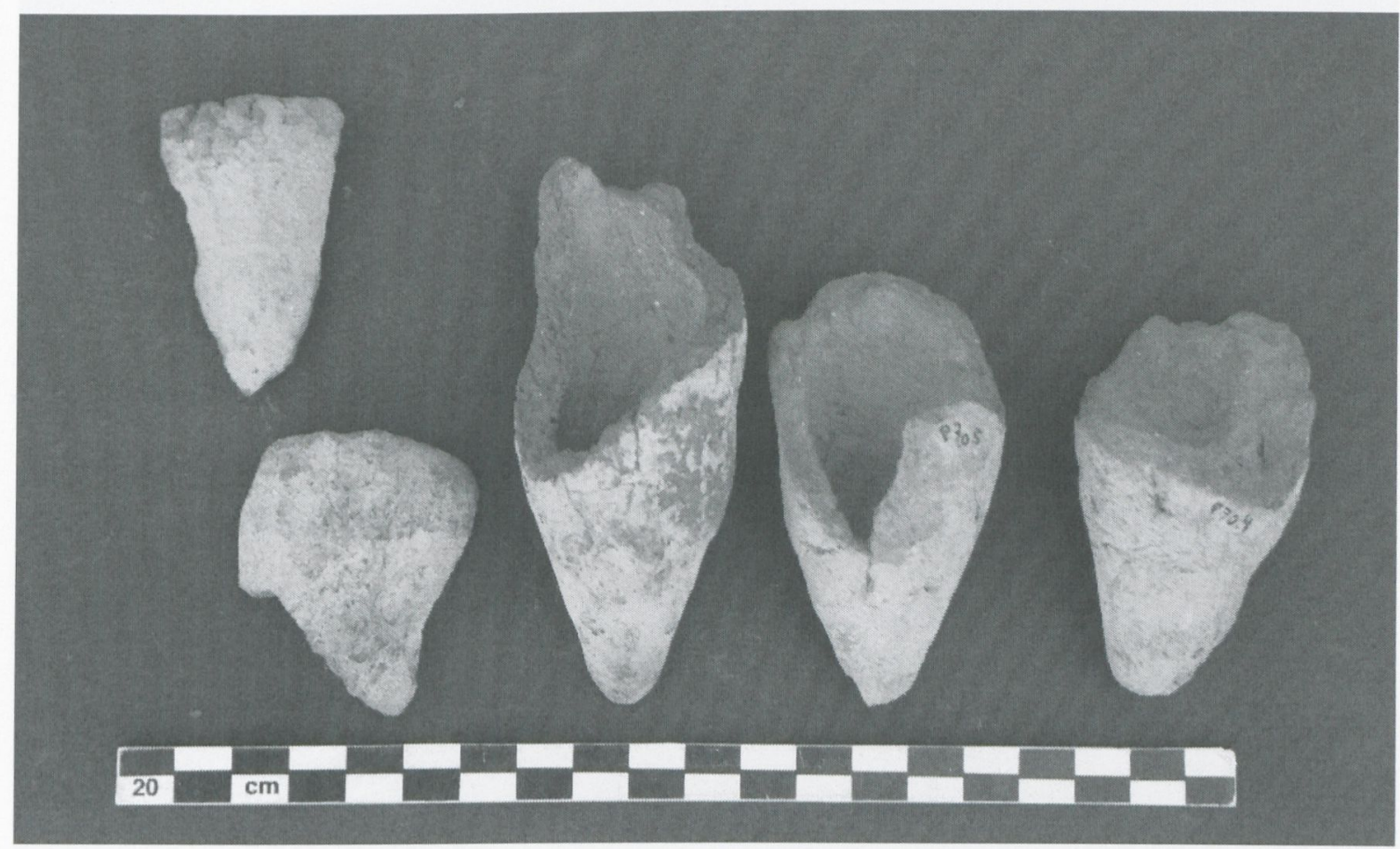

Fig. 5 - New Kingdom bread moulds from Building A. Photo: Julia Budka.

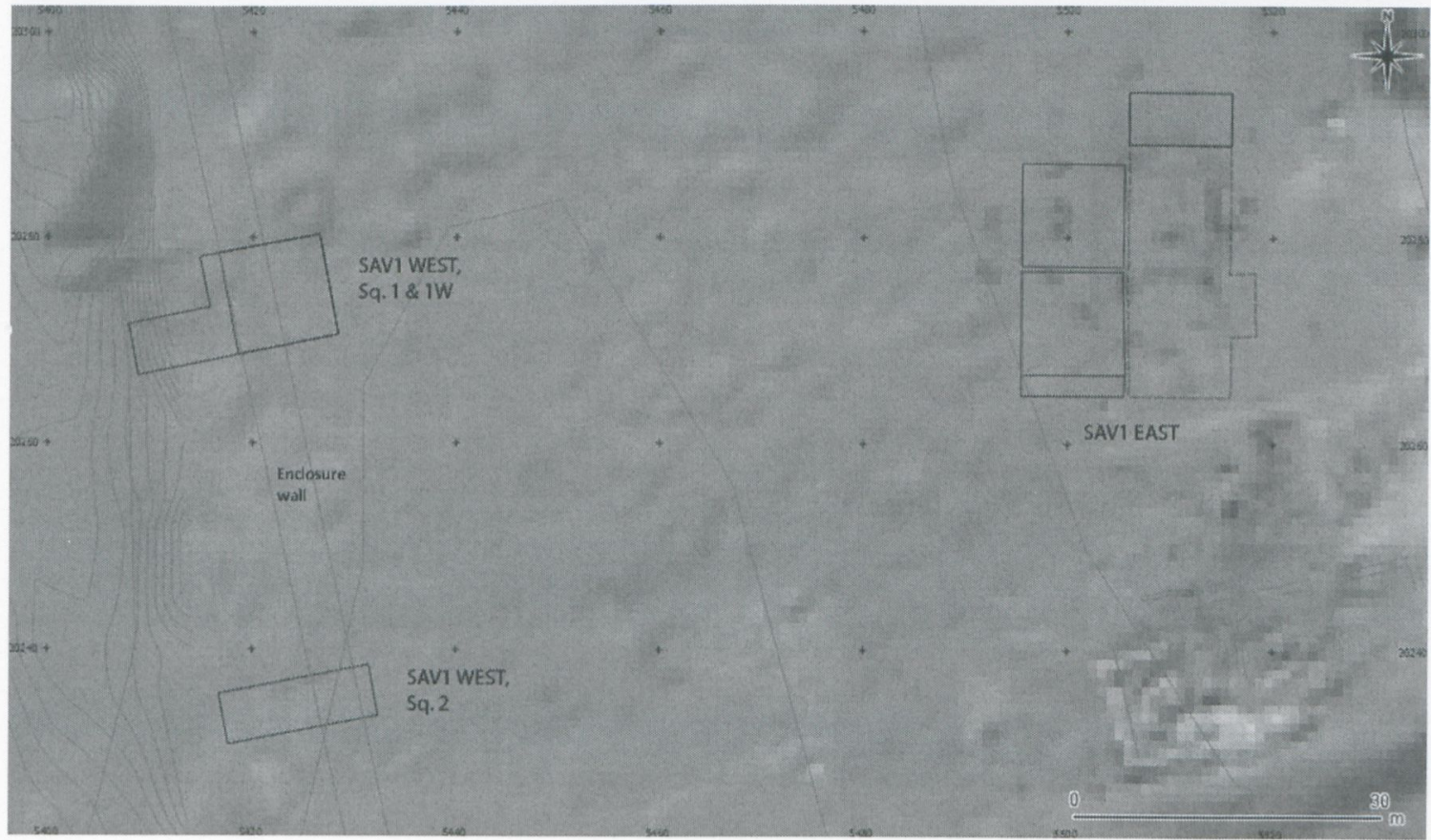

Fig. 6 - General plan of excavation squares in 2014 by Martin Fera. (C) AcrossBorders 2014. 


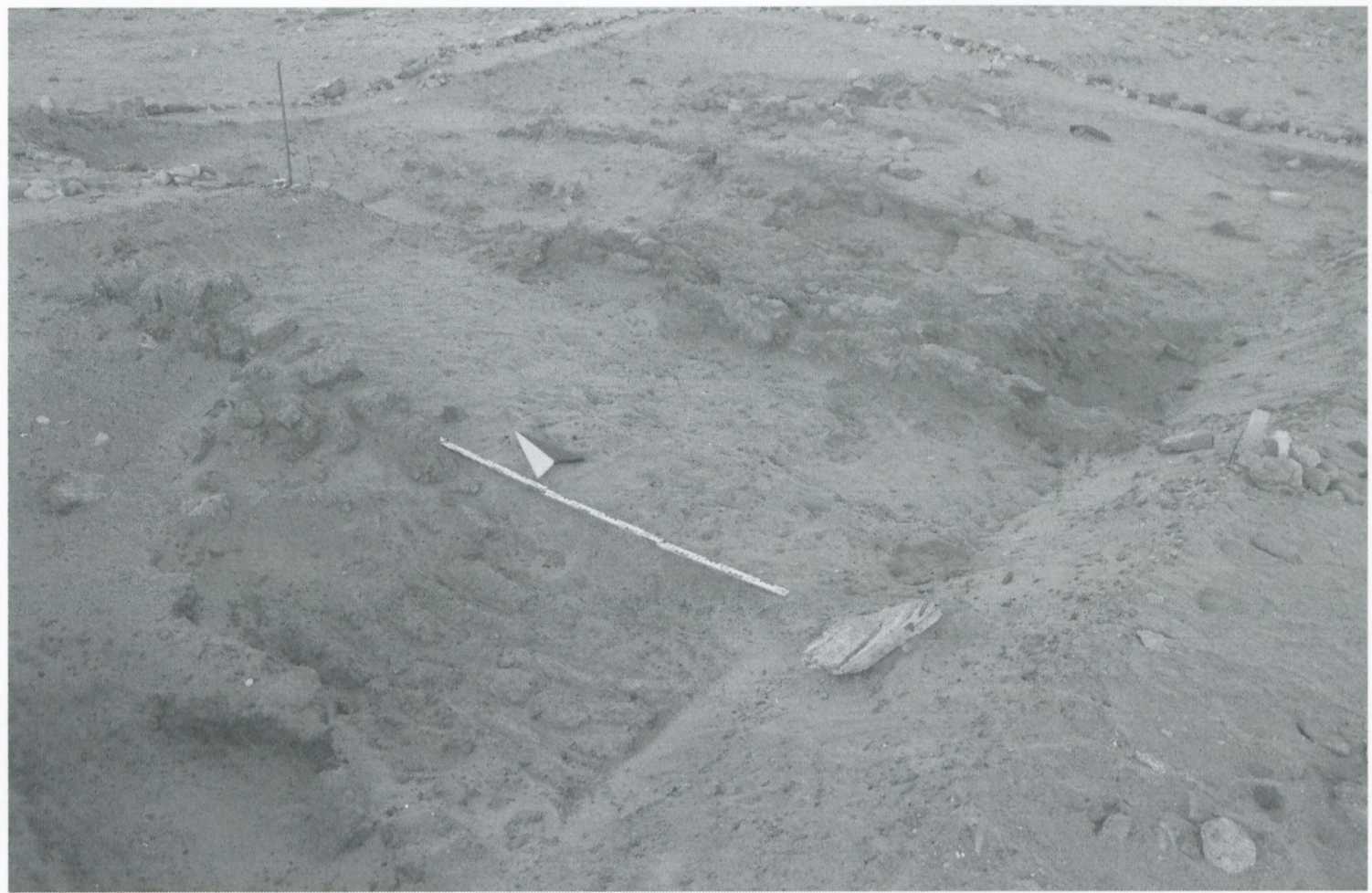

Fig. 7 - Post-New Kingdom walls/mud brick structures at SAV1 West, Square 1W; remains of the New Kingdom town wall in the background. Photo: Julia Budka. (Vd. Tav. 1)

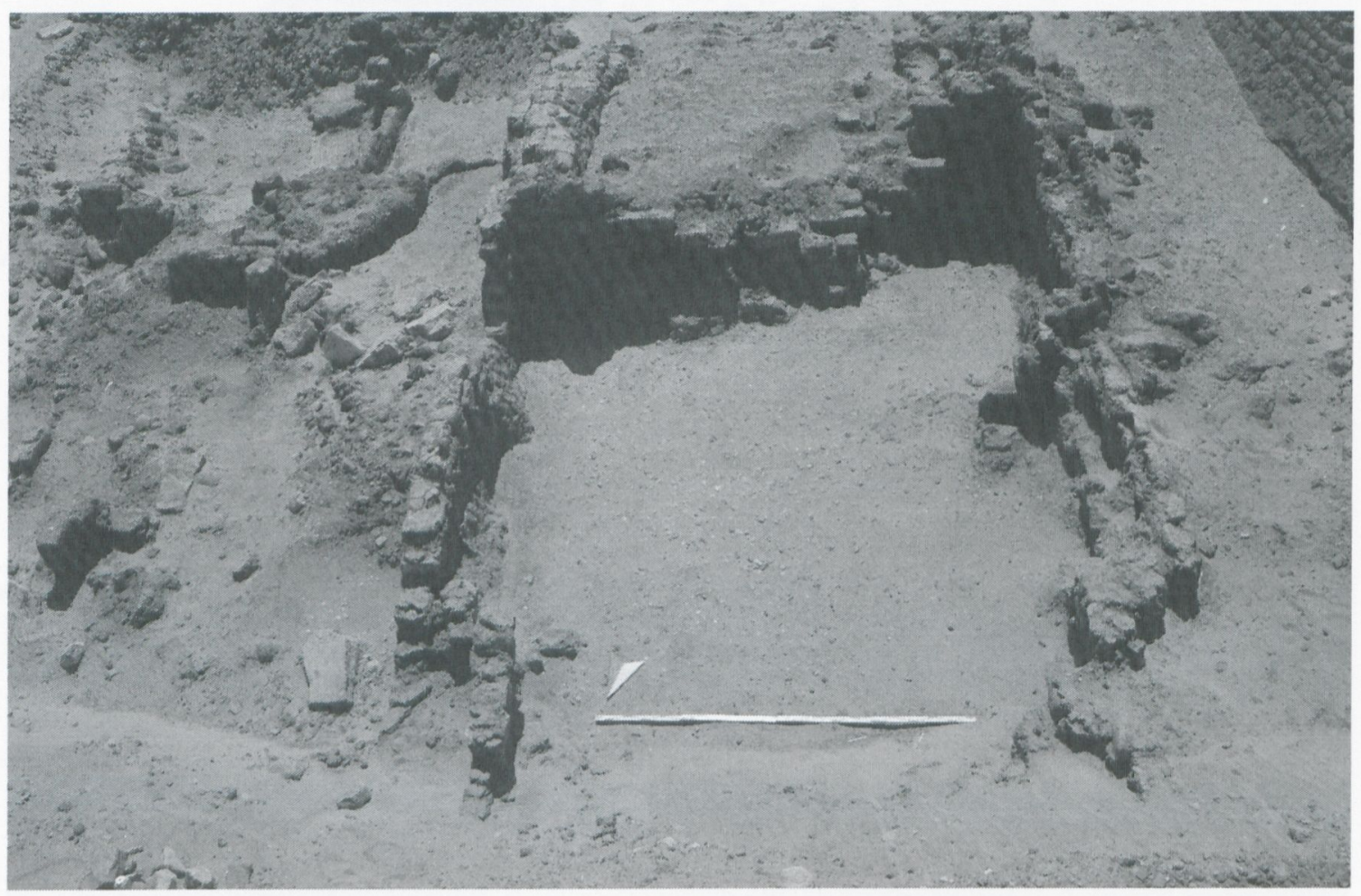

Fig. 8 - Square 1, SAV1 West: The town enclosure in the western half of the trench with substantial destruction in the northern part. Photo: Julia Budka. (Vd. Tav. 2) 


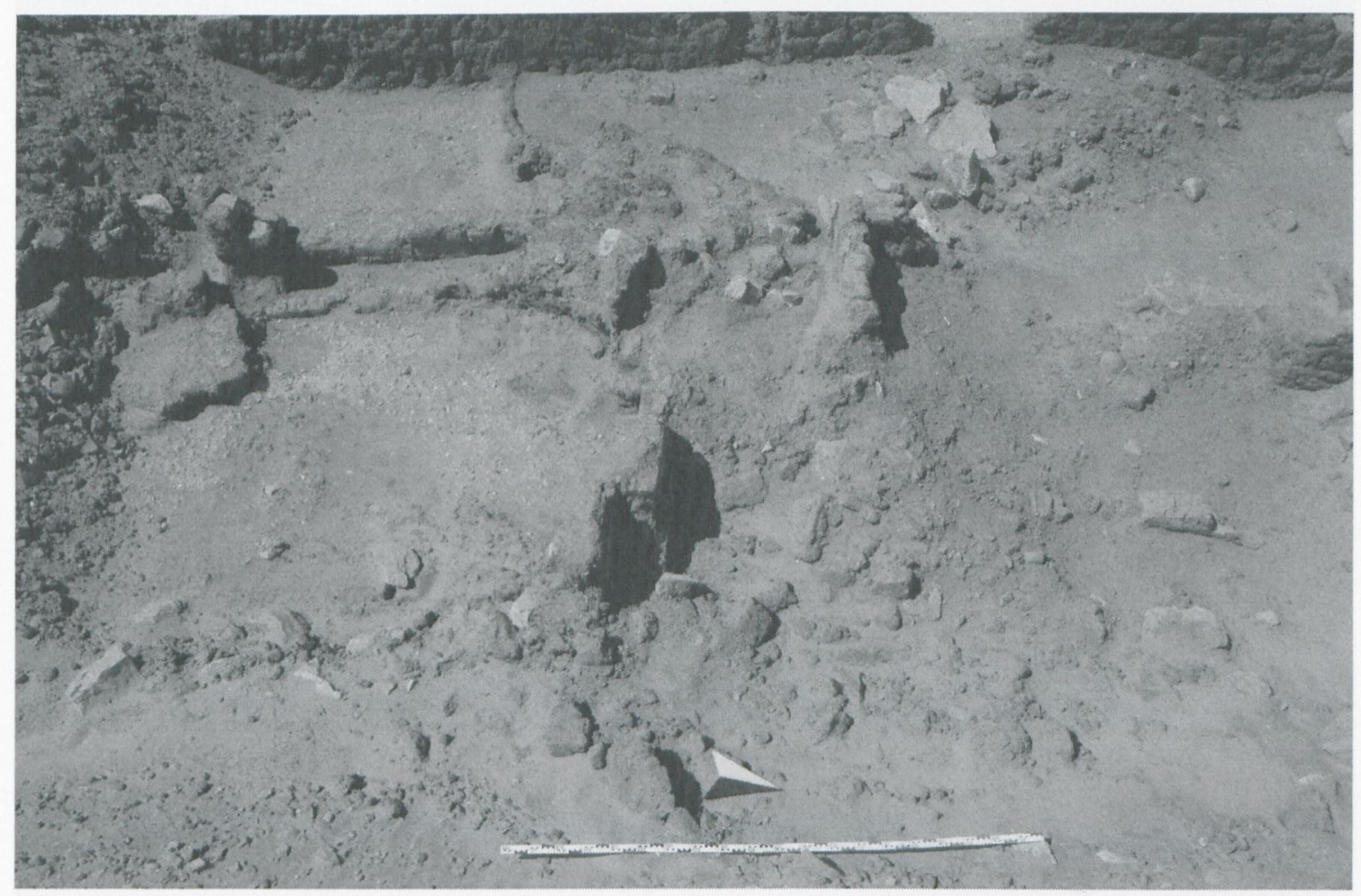

Fig. 9 - New Kingdom remains inside the fortified town at SAV1 West, Square 1 (south-eastern corner). Photo: Julia Budka. 


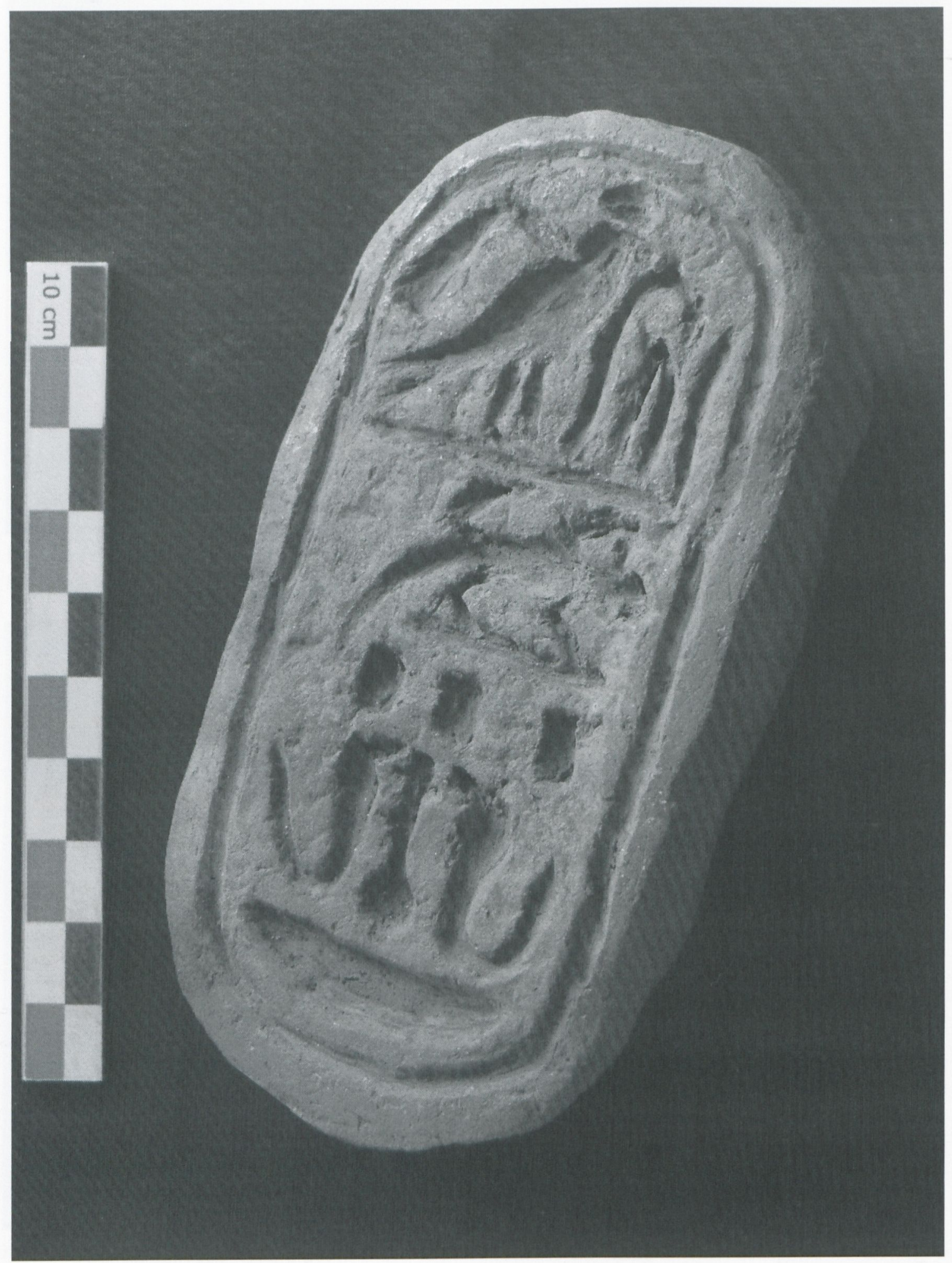

Fig. 10 - Plaque with incised hieroglyphs from SAV1 West (SAV1W 532). Photo: Julia Budka. 


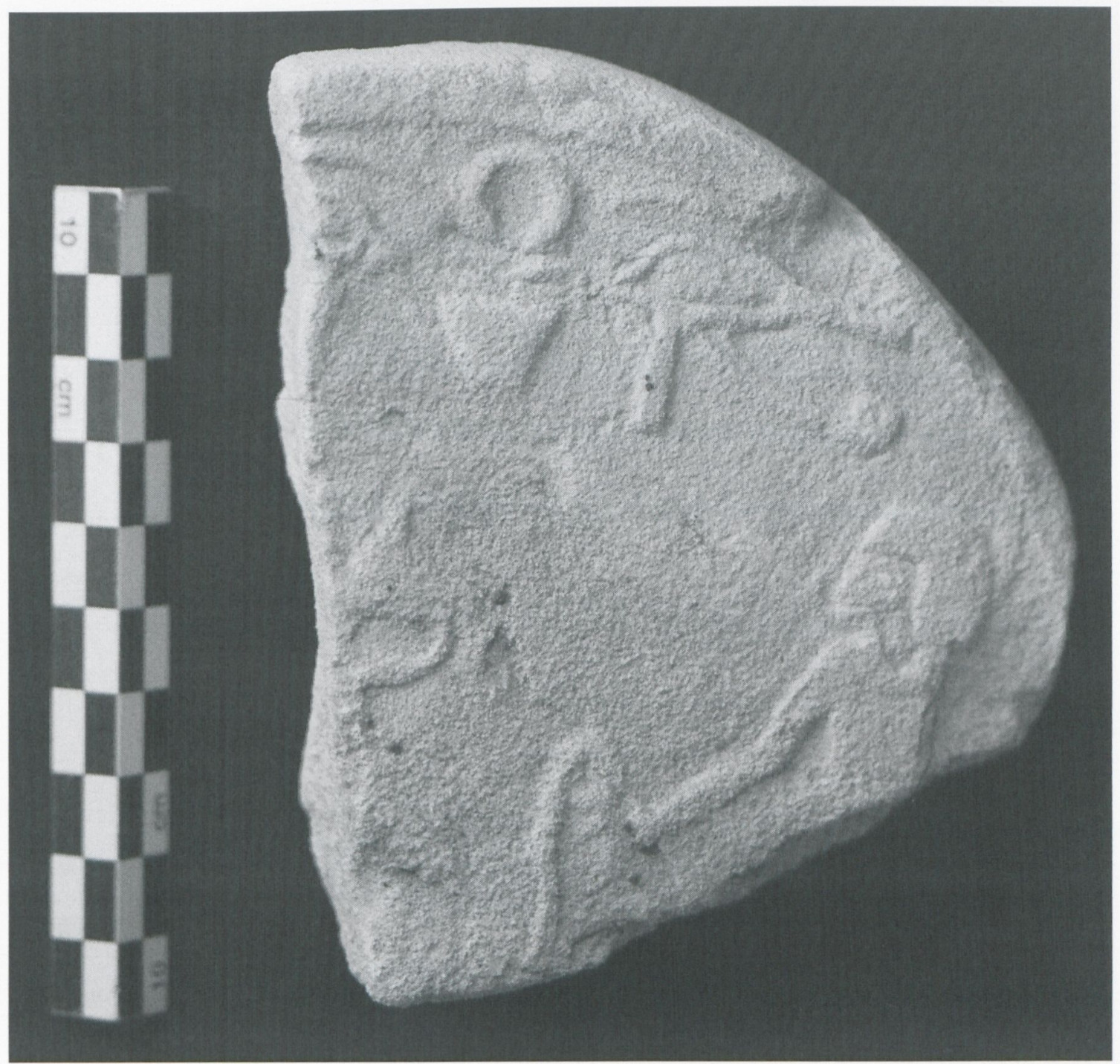

Fig. 11 - Fragmented stela from SAV1 West (SAV1W 590). Photo: Julia Budka. 


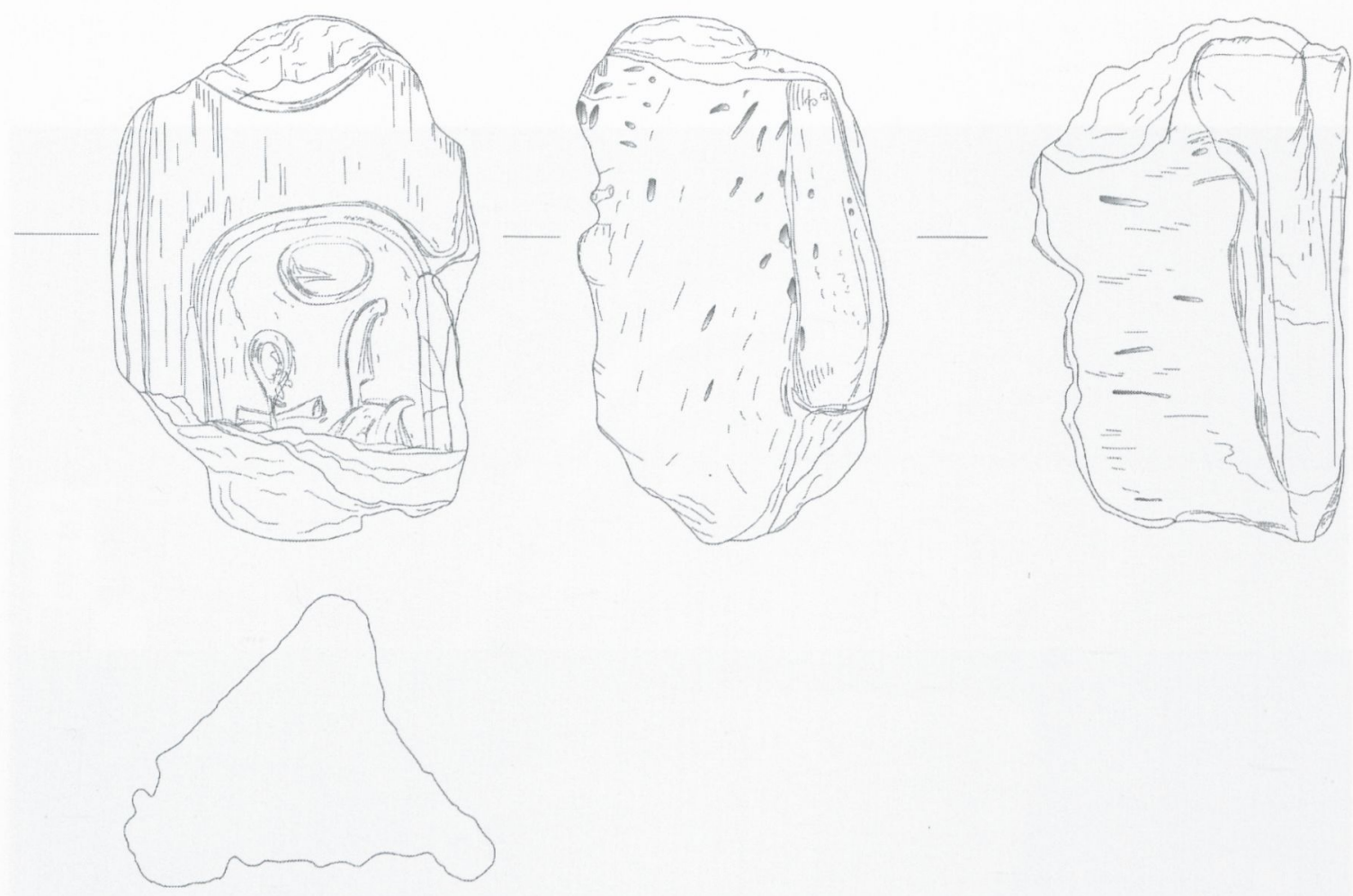

Fig. 12 - Stamped mud fragment, possibly a door sealing (SAV002). Original drawing: Julia Budka, digitalized version: Elke Schuster. Scale 1:2.
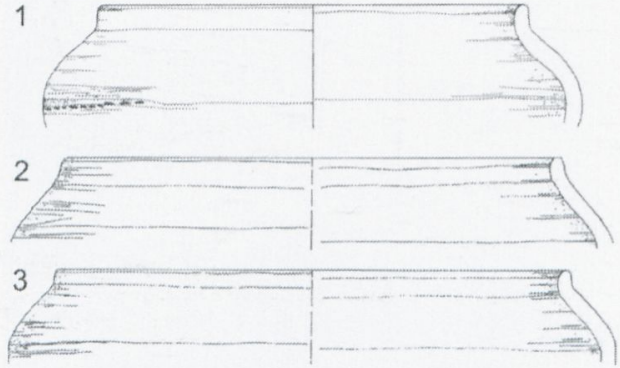

4

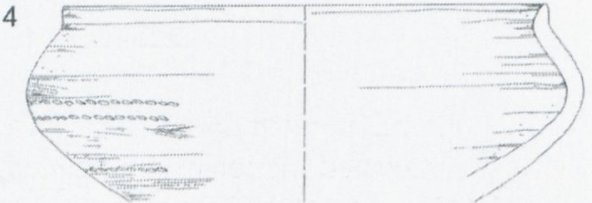

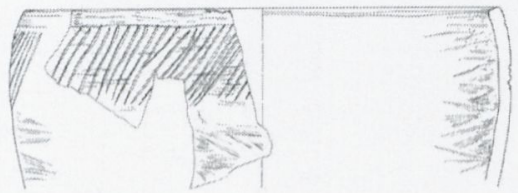

6

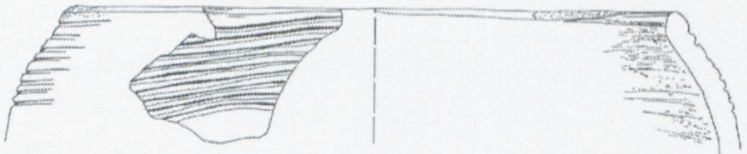

7

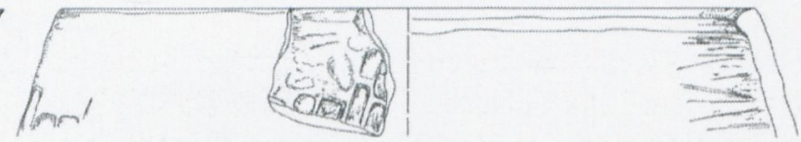

Fig. 13 - Examples of Egyptian (left) and Nubian (right) style cooking pots from the Sai Island New Kingdom town. Scale 1:6. Illustration: J. Budka. 


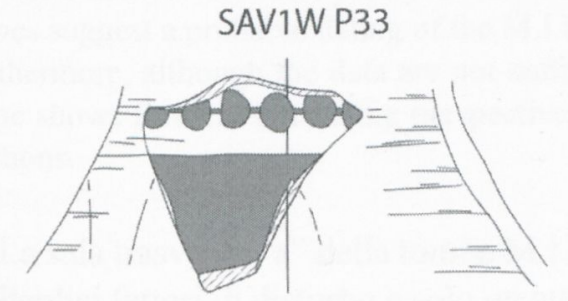

SAV1W P59.1

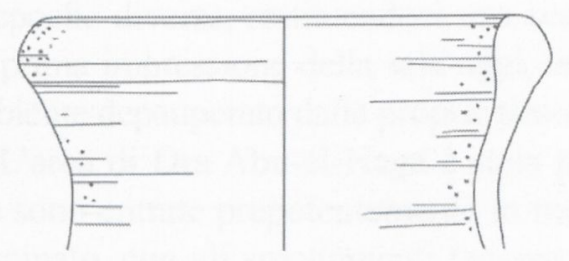

SAV1W P59.3

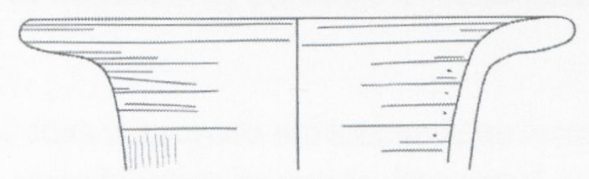

SAV1W P59.2

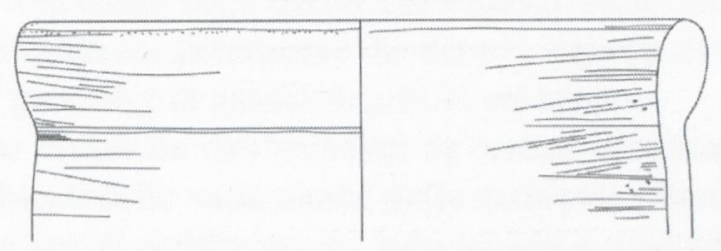

SAV1W P 78

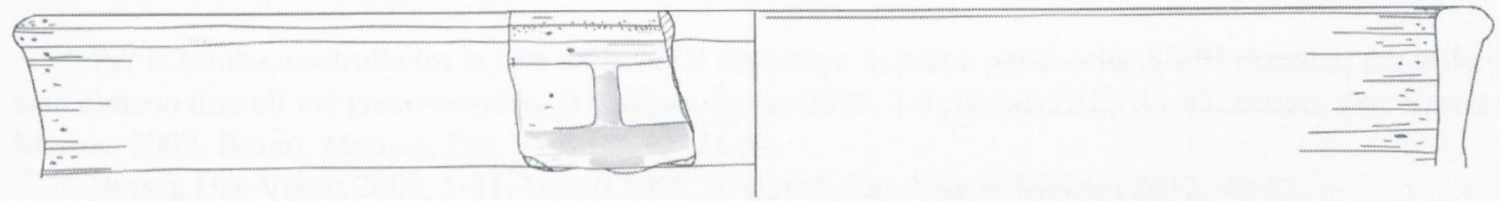

Fig. 14 - Selected imported wares found in Square 1, SAV1 West, New Kingdom Pharaonic town. Illustration: Elke Schuster. Scale 1:3. SAV1W P33: Egyptian Marl A3, uncoated monochrome painted, mid-1 $8^{\text {th }}$ Dyn.; SAV1W P59.3: Egyptian Nile B?, cream slip, mid-late 18 ${ }^{\text {th }}$ Dyn.; SAV1W P59.1: Canaanite amphora, uncoated; mid-late $18^{\text {th }}$ Dynasty; SAV1W P59.2: Egyptian Mix clay?, cream slip, Ramesside?; SAV1W P78: Egyptian Nile B2, blue painted on red wash, late $18^{\text {th }}$ Dynasty. 